\title{
SEDIMENTATION AND SEDIMENT ACCRETION IN MICHIGAN COASTAL WETLANDS (U.S.A.)*
}

\author{
R.H. KADLEC and J.A. ROBBINS \\ Department of Chemical Engineering, The University of Michigan, Ann Arbor, MI 48109 \\ (U.S.A.) \\ Great Lakes Environmental Research Laboratory, National Oceanic and Atmospheric \\ Administration, U.S. Department of Commerce, Ann Arbor, MI 48104 (U.S.A.)
}

(Accepted for publication November 30, 1983)

\begin{abstract}
Kadlec, R.H. and Robbins, J.A., 1984. Sedimentation and sediment accretion in Michigan coastal wetlands (U.S.A.). In: J.A. Robbins (Guest-Editor), Geochronology of Recent Deposits. Chem. Geol., 44: 119-150.
\end{abstract}

Sediment transport and accretion rates were studied for three different types of coastal wetlands of Lake Michigan, U.S.A. A forested intradunal wetland (Cranberry Bog No. 1) near Stevensville, Michigan, displayed sediments in the form of detritus, and exported them. Very little sedimentary material entered by streamflow. These features of bottom-land wetlands were confirmed by radioisotope studies on cores, which showed low accretion rates of ${ }^{210} \mathrm{~Pb}$. The mass fluxes were found to range from 0.01 to $0.2 \mathrm{~g}$ $\mathrm{cm}^{-2} \mathrm{yr}^{-1}$. The equivalent linear growths are $0.5-9.0 \mathrm{~mm} \mathrm{yr}{ }^{-1}$. The suspended material from this wetland entered a filling shrub-bog-lake complex known as Cranberry Bog No. 2. A considerable fraction of the incoming sediments were retained in this intradunal basin wetland. This was confirmed via radioisotope studies, with cores showing higher accretion rates than in the bottom-land wetland. The river-delta wetland at Pentwater, Michigan, had little sediment trapping ability. Large amounts of water and suspended materials entered this riverine wetland, but no annual average removal was found. Radioisotope studies of cores at selected locations within this system showed little or no accretion in stream channels, and normal accumulation of organic material in non-channel areas. No net annual effect on water quality of the streams as they discharged to Lake Michigan was found. Storm events caused no notable import or export of suspended material. Presumably the sand substrate in the vicinity of all three wetlands caused runoff events to be mediated by subsurface flow through this porous soil. These three sand-based coastal wetlands appear to have little net effect on suspended solids.

The ${ }^{210} \mathrm{~Pb}$ method proved more valuable than ${ }^{137} \mathrm{Cs}$ because of the small depth of occurrence of the latter isotope. Interpretation of isotope profiles required information on acid-fraction-soluble profiles. Results are expressed in terms of mass units, since compaction of cores distorts the linear accretion rate. Delayed transfers of radionuclides appear to have occurred, perhaps as a result of integration of atmospheric inputs by the watersheds. The total activities of ${ }^{210} \mathrm{~Pb}$ and ${ }^{137} \mathrm{Cs}$ are well correlated, which indicates particle trapping efficiency as the primary factor for affecting accumulation of both isotopes.

\footnotetext{
*Contribution No. 332 of the Great Lakes Environmental Research Laboratory.
} 
The purpose of this study was to assess the importance of wetland ecosystems in the removal of suspended sediments from waters reaching the Great Lakes. It has been thought that wetlands in general, and coastal wetlands in particular, should serve as settling basins for some of the suspended matter that reaches them by streamflow. In addition, particulate matter may reach these wetlands via overland flow from the watershed, or may be generated within the wetland as detritus. These processes have been but little studied in the past. Ranwell (1964) estimated sedimentation rates in marshes in England in the range of $0.2-10.0 \mathrm{~cm} \mathrm{yr} .^{-1}$. Similarly, Richard (1978) found sedimentation rates in a Long Island, New York, salt marsh to range from 1 to $5 \mathrm{~cm} \mathrm{yr} .^{-1}$, depending upon vegetation and elevation. DeLaune et al. (1978) measured sedimentation rates in a Gulf Coast, New Mexico, salt marsh. Radiotracer methods determined sedimentation rates on the order of $0.7-1.4 \mathrm{~cm} \mathrm{yr.}^{-1}$.

Tilton et al. (1978) speculated that the North America Great Lakes coastal wetlands trapped and stabilized sediments, and consequently reduced turbidity in stream and runoff waters reaching the Great Lakes. However, they found little to support this contention. They postulated that the vegetation type would be an important variable in the process of removal of suspended material from flowing waters.

Consequently, this study was designed to obtain information on the amounts and concentrations of suspended materials entering and leaving coastal wetlands. The hydrology of the sites was determined approximately, and suspended solids were measured. Variations in water level were monitored. Sediment accumulation rates within these wetland systems were estimated using radio-tracer techniques. Water and suspended-solids budgets for these ecosystems were estimated. The influence of short-term rainfall events of variable intensity were investigated by high-frequency sampling for two of the ecosystems.

Boto and Patrick (1979) present a literature review on sedimentation processes in freshwater wetlands, but found only a few publications of direct relevance. Kadlec and Kadlec (1979) document the gross removal of suspended solids in wetland ecosystems that are being used for wastewatertreatment processes. They find some of these wetlands serve as retention areas, while others apparently serve as discharge areas for solids.

Although radiometric methods for dating recent deposits have enjoyed increasing use over the past decade [see Robbins (1978) for a review], there have been very few applications to wetlands (see Armentano and Woodwell, 1975; DeLaune et al., 1978; Oldfield et al., 1979). The ${ }^{210} \mathrm{~Pb}$ method in particular, has been shown to provide a chronology of coastal marine and lacustrine sediments which can extend back in favorable cases as far as $\sim 150 \mathrm{yr}$. Thus, in principle, the ${ }^{210} \mathrm{~Pb}$ should provide a suitable dating method since wetland strata will generally undergo appreciable 
growth in that time span. Oldfield et al. (1979) have applied the method to establish a chronology for growth of ombrotrophic peat deposits in Great Britain with apparent success.

The ${ }^{210} \mathrm{~Pb}$ method is based on certain remarkable and fortunate properties of the $U$ decay series. ${ }^{226} \mathrm{Ra}$, present almost universally in crustal materials, decays to form the inert noble gas ${ }^{222} \mathrm{Rn}$. This gas escapes from surface materials (rocks and soils) into the atmosphere where it decays with a 3.8day half-life. Rn decays through a series of very short-lived intermediate products to ${ }^{210} \mathrm{~Pb}$ which has a 22.3-yr. half-life. Unlike $\mathrm{Rn}, \mathrm{Pb}$ is quite reactive in the atmosphere. Becoming attached to particles once formed, it is efficiently removed from the air primarily through precipitation and deposited among other places on water bodies where it is rapidly incorporated into sedimentary materials. Often, rapidly accumulating deposits have a considerable excess of ${ }^{210} \mathrm{~Pb}$ over that which is produced locally by the decay of $\mathrm{Rn}$ and its $\mathrm{Ra}$ parent. Decay of excess ${ }^{210} \mathrm{~Pb}$ on burial or, in the case of wetlands, on the growth of peat layers, provides the basis for a chronology. However, a valid chronology can be developed only if the characteristics of deposition of the isotope as well as any postdepositional migration, sorting of materials or nonconformities in accretion processes can be properly understood. It may be expected that the examination of the distribution of this isotope can provide insights into the nature of the accretion process.

Another isotope suitable, in principle, for chronological studies is ${ }^{137} \mathrm{Cs}$. This man-made radionuclide (half-life $30 \mathrm{yr}$.) is distributed around the globe as a result of the atmospheric testing of nuclear weapons which reached a peak in the mid-1960's. The first appearance of the isotope in sediments can be generally associated with a time of about 1955. Thus, a horizon of ${ }^{137} \mathrm{Cs}$ corresponds to $\sim 27 \mathrm{yr}$. B.P. provided there are no processes occurring which redistribute the isotope within the sediments. While selected lacustrine environments (such as the Great Lakes) possess sediments in which little diffusional mobilization of Cs appears to occur, the isotope appears to be mobile in accreting organic sediments in wetlands (cf. Pakarinen and Tolonen, 1977). Therefore its use in the present case remains open to question.

\section{SITE DESCRIPTIONS}

Three sites were chosen for the studies. Cranberry Bog No. 1 is an intradunal wetland near Stevensville, Michigan. It is a bottom-land forested wetland consisting of mixed hardwoods and softwoods with an understory of various shrubs. It is surrounded by dunes of $\sim 30 \mathrm{~m}$ in height. The wetland contains organic deposits $\sim 50 \mathrm{~cm}$ thick. The wetland receives streamflow from the Livingston Valley drain to the south and discharges through a streamflow to the north. The stream dissipates within $100 \mathrm{~m}$ of entering the wetland into diffuse sheetflow, and narrows at the exit of the outlet of the 
wetland to a slowly moving broad vegetated outflow to the next ecosystem. The wetland area is $\sim 65$ ha.*

Cranberry Bog No. 2, also $\sim 65$ ha, receives this streamflow, but is an entirely different ecosystem. It appears to be an intradunal lake that is filling by detrital accumulation from the edges. The central regions of Cranberry Bog No. 2 are open water of indeterminate depths. The bottom of this lake area contains several meters of poorly consolidated flocculent sediments. The edge zones of this ecosystem consist of a shrub-cattail community which averages a $100 \mathrm{~m}$ or more in width. An interlaced root zone lies less than $1 \mathrm{~m}$ below the surface of the water in this region. Several

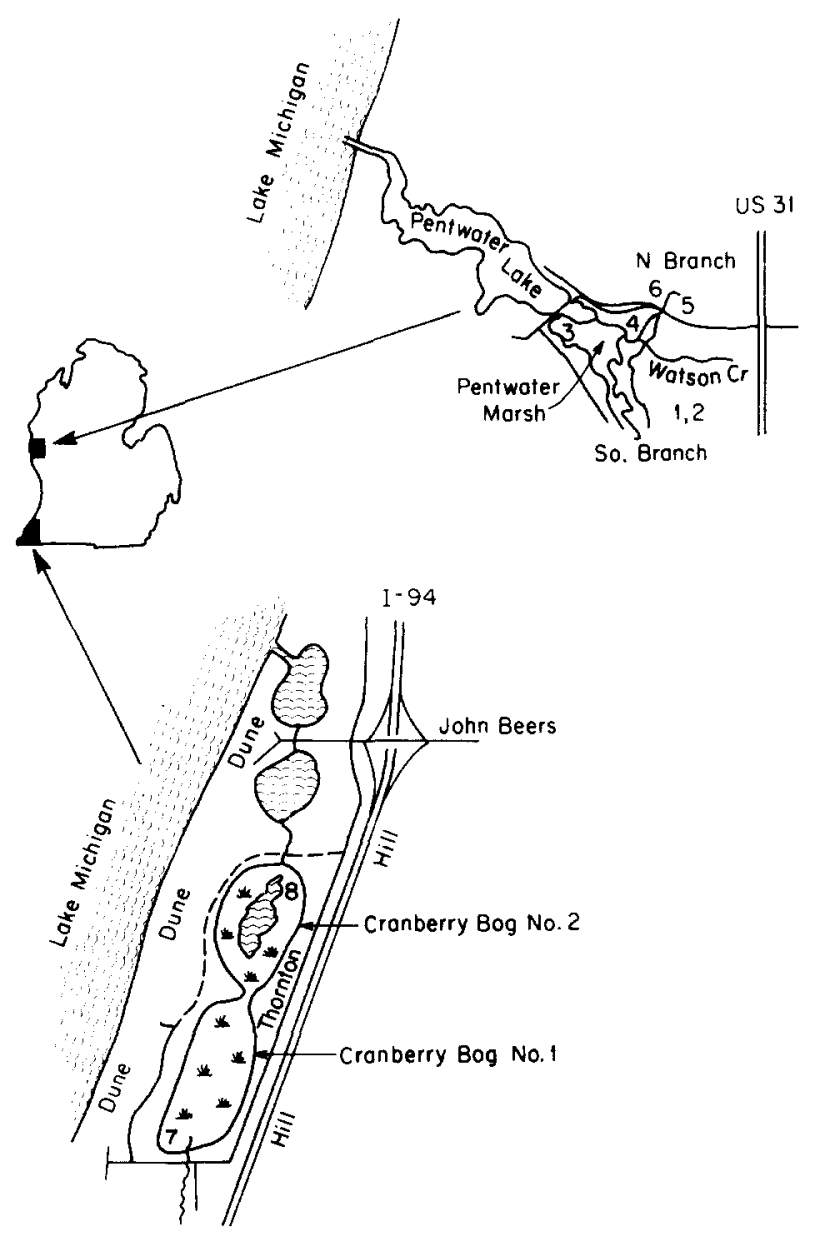

Fig. 1. Locations of wetland study sties. All three wetlands are $\sim 65$ ha, Numbers refer to sediment core locations.

$* 1 \mathrm{ha}=1$ hectare $=0.01 \mathrm{~km}^{2}$. 
areas of this wetland contain floating mats of vegetation. Waters from Cranberry Bog No. 2 exit through a well-defined stream to two intradunal lakes, Grand Mere Lakes, which then discharge immediately to the northwest to Lake Michigan. These wetlands and lakes are parallel in orientation to the shoreline of Lake Michigan as shown in Fig. 1. The distance from Lake Michigan to either wetland is only a few hundred meters.

The third study site is located near Pentwater, Michigan, as shown in Fig. 1. This 65-ha wetland is a delta ecosystem where the north and south branches of the Pentwater River combine with Watson Creek and discharge into Pentwater Lake. Pentwater Lake is very closely coupled to Lake Michigan; and consequently wind, tide and seiche effects are felt at the outlet of this wetland. The upstream sections of this wetland are sedgeand shrub-covered floodplain wetlands. The downstream sections are inundated cattail and pond areas. Most of the waterflow is channeled, except at times of extreme high water. The surrounding topography at the Pentwater site is similar to that at the Cranberry Bogs sites.

In highly simplified terms, Cranberry Bog No. 1 is a forested bottom land swamp, Cranberry Bog No. 2 is a filling-lake system, and Pentwater is a river-delta wetland.

\section{HYDROLOGY}

\section{Methods}

Streamflows to the wetlands were determined by measuring the velocity of the stream using a turbine meter where depth permitted, and using neutral density trancers where depths were insufficient. The inflow to Cranberry Bog No. 1 was through a culvert as was the outflow from Cranberry Bog No. 2. Thus, accurate measurements of the width and depth of these streams could be made. The flow from Cranberry Bog No. 1 to Cranberry Bog No. 2 was diffuse, across a channel $\sim 25 \mathrm{~m}$ in width. It was virtually impossible to ascertain the geometry of this channel, and consequently no flow measurements could be made at this point.

Streamflow measurements at the Pentwater Marsh presented different difficulties. Measurements were made with a turbine meter or with a neutral density tracers as at Cranberry. However, the south branch of the Pentwater River could be waded at several locations, consequently a depth profile and several velocity measurements could be made. The north branch of Pentwater River passed through a well-defined channel underneath a bridge, and similar measurements could be made at that point. These two flow estimates are therefore quite good. Watson Creek also enters this wetland, but it is an intermittent rivulet which contributes little to the total inflow. This flow was visually estimated. The outflow from Pentwater Marsh is dependent upon lake level, wind, tide and seiche activity. Sometimes, inflow occurred. Thus, even though there is a well-defined concrete bridge channel, there is 
little hope of accurately measuring flows at this point without sophisticated equipment.

Water levels were measured at all wetlands at times of sampling visits. Evapotranspiration was estimated for each wetland site using the Thornthwaite and Mather (1957) method. Precipitation records were taken from the nearest National Oceanic and Atmospheric Administration (N.O.A.A.) weather station for the Cranberry Bogs, Dowagiac, Michigan; and were estimated for the Pentwater site on an annual basis. The net recharge or discharge for the wetland was estimated by difference from the overall water budget.

\section{Results}

Fig. 2 shows the flows and net precipitation less evapotranspiration for combined Cranberry Bogs. Outflow and inflow are generally in phase, with low flows occurring in the summer months and high flows occurring in late winter and early spring. There is a spring runoff peak occurring in late February and early April, and another high runoff event occurring in early May. Fig. 3 displays the response of the water surface elevation near the outlet of Cranberry Bog No. 2 to these inflow-outflow events. Levels are relatively low during the late summer and early fall months, and are elevated $\sim 15 \mathrm{~cm}$ during the late winter and early spring months. The two runoff events also appear in water-level records for this location.

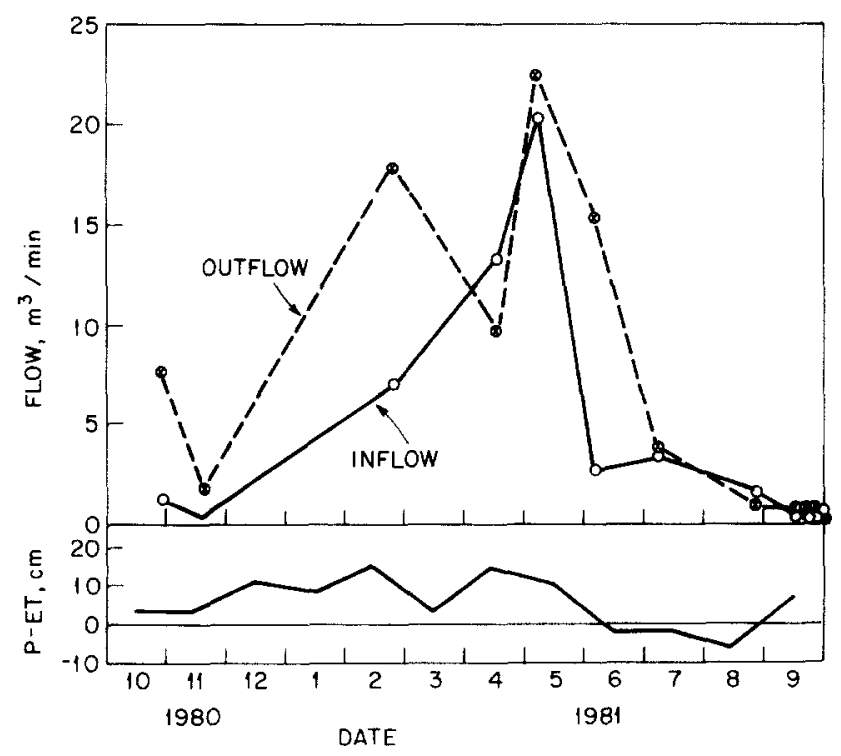

Fig. 2. Water-budget elements for the combined Cranberry Bogs. Streamflows vary widely during the year in response to seasonal changes in precipitation less evapotranspiration. 


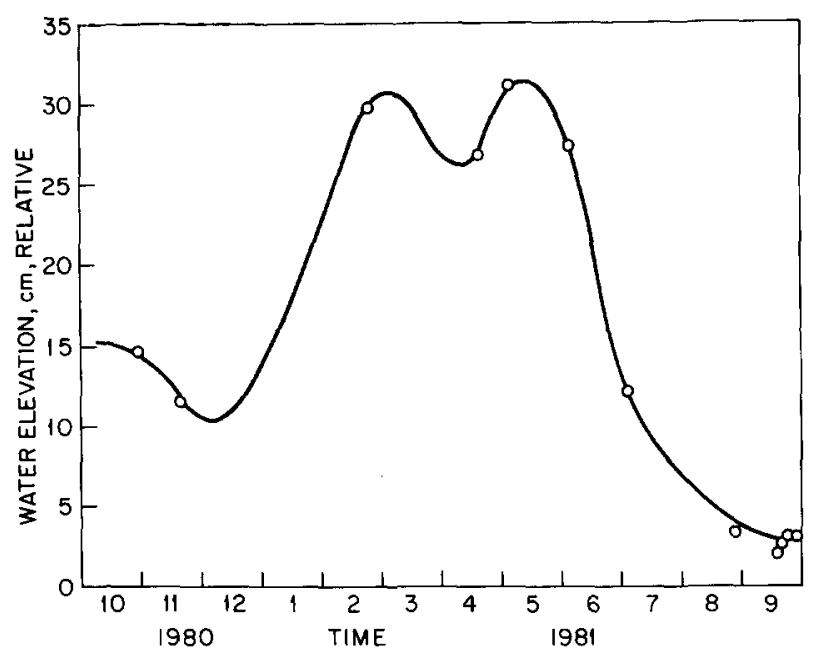

Fig. 3. Water surface elevation near the outlet of Cranberry Bog No. 2. The datum is the top of a concrete bridge (destroyed) abuttment less $115.0 \mathrm{~cm}$. Seasonal effects are noticeable, and correlate properly with streamflow.

The above information can be combined into a water budget for these two wetlands as shown in Fig. 6. The recharge and discharge for the combined wetlands was apportioned equally between the two ecosystem types for the Cranberry Bogs in this figure. This two-wetland complex is seen to be an annual discharger of water. This is not unexpected, since subsurface flow though the porous sandy soils that surround the wetlands quite clearly contributes to the surface waters of these wetlands.

The Pentwater Marsh was studied at less frequent intervals, and thus insufficient information is available on the seasonal flow regime. However, Fig. 9 shows an estimate of the water budget for this wetland based on that information. In addition, there is a question concerning the outflow from this wetland, which is strongly linked to the Lake Michigan hydrologic regime. Nonetheless, as can be seen from Fig. 9, streamflow clearly predominates over evaporation and precipitation events for this wetland.

\section{SUSPENDED SOLIDS}

\section{Methods}

Triplicate water samples were taken from all inflows and outflows for the wetlands, on fifteen occasions during the year for the Cranberry Bogs, and on five occasions during the year for the Pentwater Marsh. Hydrologic measurements were also taken at those times. The 1-gal. (3.785 1) samples were returned to the laboratory and analyzed for total and volatile sus- 
pended solids (A.P.H.A., 1975). Large detritus, mostly duckweed (Lemna sp.) and floating leaves, was excluded from the samples as being uncharacteristic of the water-borne component of the solids load.

\section{Results}

Figs. 4 and 5 show the total suspended-solids concentrations in the entering and leaving waters of the two Cranberry Bogs and Pentwater Marsh. In both cases, the suspended-solids contents of inflow and outflow are remarkably in phase. In both cases there is a pronounced winter maximum for suspended solids. The highest concentrations of solids leaving and entering these wetlands occurs during the November-February period. It is also apparent that there is little, if any, change in concentration between the inlet and outlet waters from these systems.

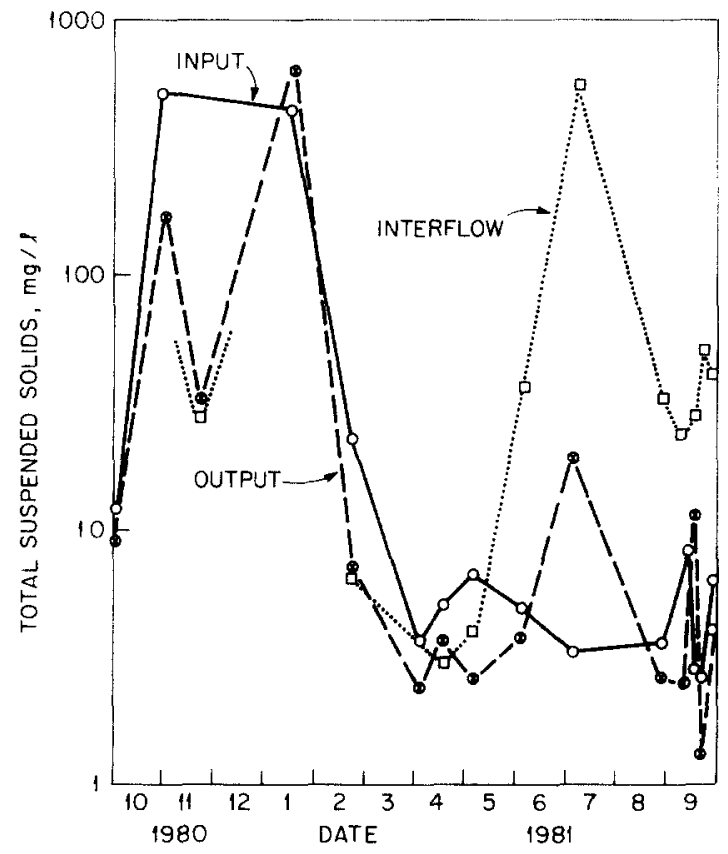

Fig. 4. Suspended solids in waters entering and leaving the Cranberry Bogs. Inputs and outputs of the combined bogs are low in summer and high in fall and early winter. Large summer exports from No. 1 are absorbed in No. 2 .

During the summer months, the suspended-solids concentration leaving Cranberry Bog No. 1 and entering Cranberry Bog No. 2 was considerably greater than the entering or leaving streams. It was at comparable levels during the fall, winter and spring months.

The above information may be combined with the water-budget informa- 


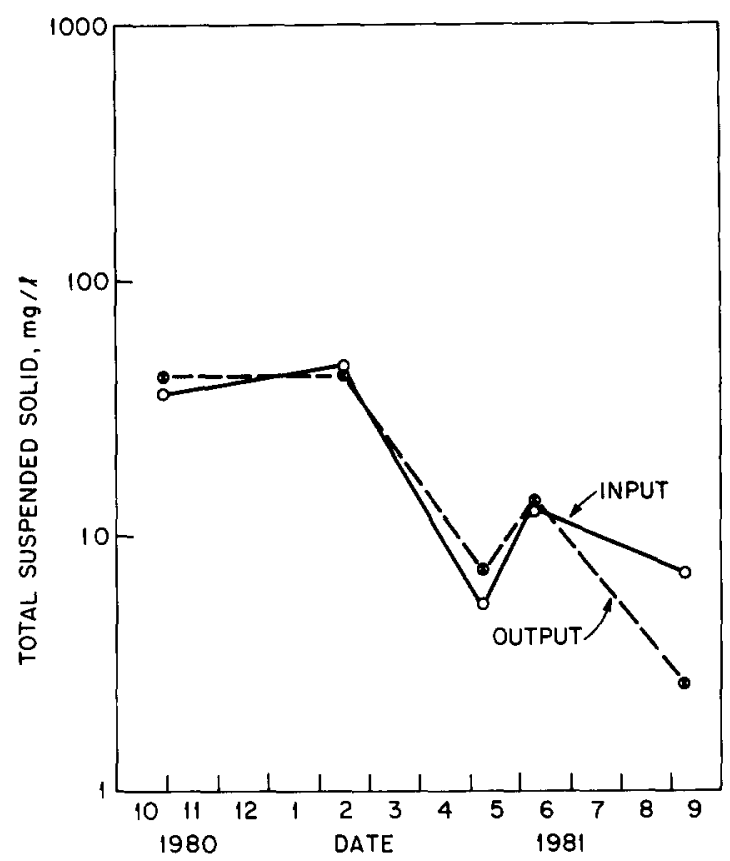

Fig. 5. Suspended solids entering and leaving Pentwater Marsh. Both are high in late fall and low in summer. Concentrations are not far different.

tion to yield the budgets for suspended materials entering and leaving the water compartment at these wetland sites. This information is presented in Figs. 6-8 for the Cranberry Bogs and in Figs. 9-11 for the Pentwater Marsh. Although no information is available on air-borme sediments, the picture for water-borne sediments is relatively clear. Annually Cranberry Bog No. 1 is a net exporter of water-borne suspended materials, and Cranberry Bog No. 2 acts as a retention basin. In Fig. 8 the internal cycling of the organic detritus is estimated along with the imports and exports on an areal basis. The internal cycling for the open-water bog is estimated to be less than that for the forested bottomland. Here the net process seems to be the accretion and export of incoming and generated material from the bottomland forest, and the retention of incoming material and internally generated material.

The comparable information for the Pentwater Marsh is displayed in Figs. 9-11. On an annual basis the Pentwater Marsh appears to have no effect on the solids load reaching the Pentwater Lake and then Lake Michigan. Even though the concentration of suspended material in the Pentwater River is far less than it is for the streams in the Cranberry complex, the tremendously greater streamflow means a great increase in the amount of material that is transported through this wetland ecosystem. Consequently, any estimate of internal cycling will turn out to be considerably less of an input to this ecosystem than streamflows. 


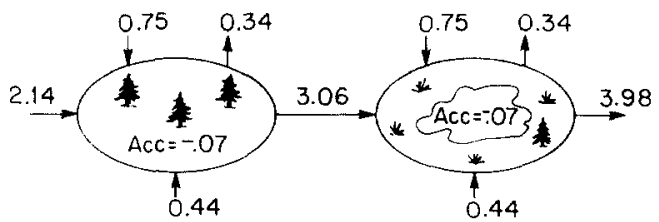

Fig. 6. Annual water budget (in $10^{6} \mathrm{t}_{\mathrm{yr}}{ }^{-1}$ ) for the Cranberry Bogs. Streamflow is larger than subsurface discharge, which is comparable to precipitation less evapotranspiration. Streamflow increases as the lower parts of the watershed are reached.

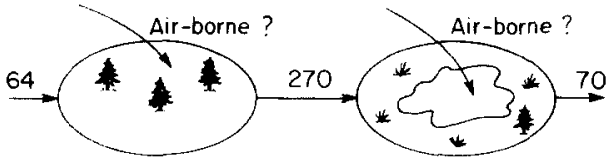

Fig. 7. Annual suspended solids flows (in $\mathrm{t} \mathrm{yr}^{-1}$ ) for the Cranberry Bogs. No. 1 is an exporter; No. 2 is a retention basin.

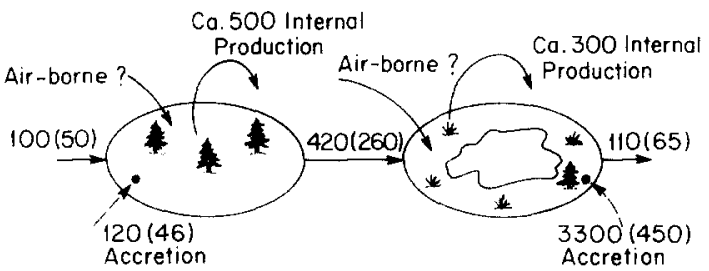

Fig. 8. Annual average solids fluxes and accretions (in $\mathrm{g} \mathrm{m}^{-2} \mathrm{yr}^{-1}$ ) for the Cranberry Bogs. Crude estimates of internal productions (detritus) are included. Numbers in parentheses are volatile solids. Accretion is higher in lower parts of the watershed.
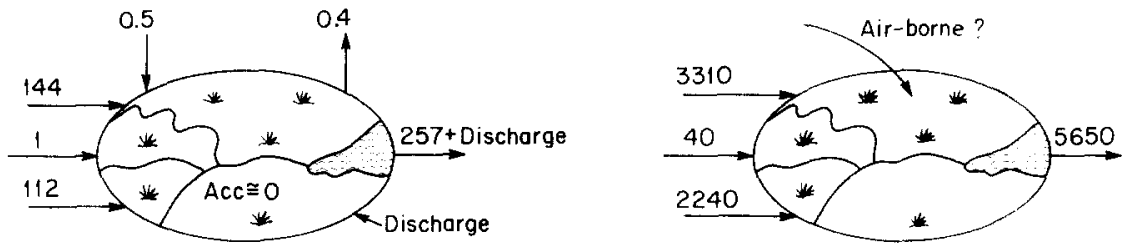

Fig. 9. Annual water budget (in $10^{6} \mathrm{t} \mathrm{yr}^{-1}$ ) for Pentwater Marsh. Subsurface discharge was not measured. Lake Michigan influences levels and outflows due to winds, tides and seiches.

Fig. 10. Annual suspended solids flows (in $\mathrm{t} y r^{-1}$ ) for Pentwater Marsh. Approximately equal amounts enter and leave.

Fig. 12 shows the short-term effects of rainfalls on the discharge and retention of suspended material in Cranberry Bogs system. Between August 27 and September 30, 1981, six separate rain events occurred in this area. Water samples and hydrologic measurements were taken at 5 times throughout the same interval. There were no pronounced effects on water flows 
or the suspended-solids load at any location during these events. Suspendedsolids load of Bog No. 1 inlet and Bog No. 2 outlet remained low and the inter-bog flow remained somewhat higher throughout the 30-day period.

The nature of the suspended solids at both locations, as measured by the per cent of the solids which are volatilized at $550^{\circ} \mathrm{C}$, is $\sim 50 \%$ volatile or organic. There is no dramatic change in the percentage volatile from inlet to outlet in any of the wetland systems studied. However, the $50 \%$ of the solid material which was non-volatile should be, and was, reflected in the fraction of the accreted sediments which were solubilized from cores.

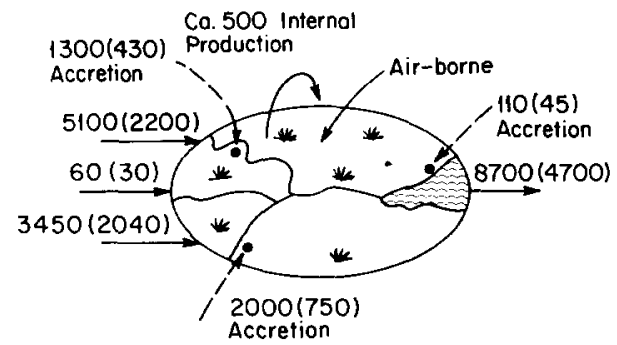

Fig. 11. Annual average solids fluxes and accretions (in $\mathrm{g} \mathrm{m}^{-2} \mathrm{yr}^{-1}$ ) for Pentwater Marsh. Streamflow is larger than estimated production. Accretion is high in the floodplain areas, but low in the lake-influence zone.

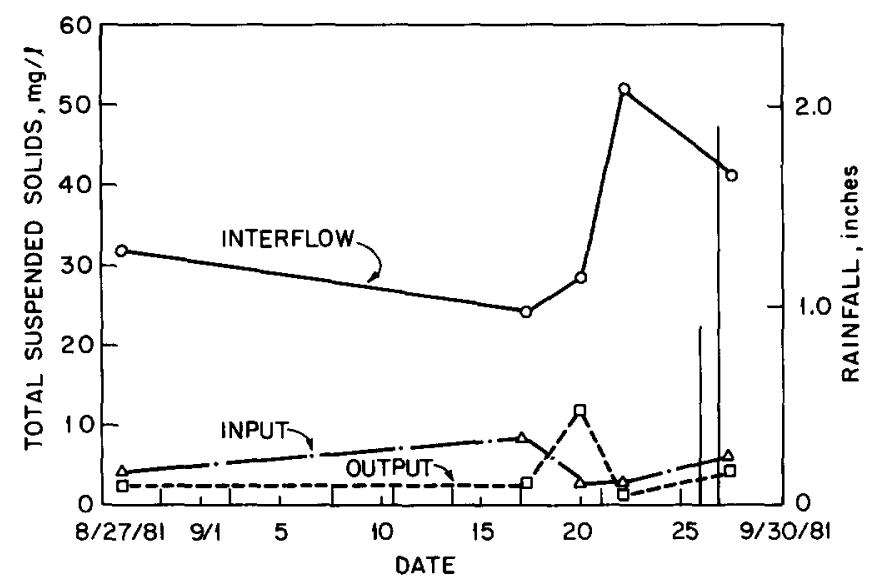

Fig. 12. The effect of rain events on solids imports and exports for the Cranberry Bogs. Little if any response is indicated, even for the torrential storm of September 27, 1981.

\section{WATER QUALITY}

\section{Methods and results}

Background information on water quality was determined at one sampling date for each of the wetland systems. This information provides confirma- 
tion of water budgets and internal cycling and generation. Water samples were analyzed in the laboratory for $\mathrm{pH}$, conductivity, chloride and ammonium nitrogen, using electrode methods and total dissolved phosphorus was determined using a colorimetric method. The results of these measurements, indicated in Table I, show relatively low levels of dissolved nutrients and dissolved solids in the waters in these wetlands ecosystems.

\section{TABLE I}

Water quality parameters for the study sites

\begin{tabular}{|c|c|c|c|c|c|}
\hline & $\mathrm{pH}$ & $\begin{array}{l}\text { Conductivity } \\
\left(\mu \mathrm{S} \mathrm{cm}^{-1}\right)\end{array}$ & $\begin{array}{l}\mathrm{Cl}^{-} \\
\left(\mathrm{mg} \mathrm{l}^{-1}\right)\end{array}$ & $\begin{array}{l}\mathrm{NH}_{4}^{+}-\mathrm{H} \\
\left(\mathrm{mg} \mathrm{1}^{-1}\right)\end{array}$ & $\begin{array}{l}\text { TDP } \\
\left(\mathrm{mg} \mathrm{l}^{-1}\right)\end{array}$ \\
\hline \multicolumn{6}{|c|}{ Cranberry Bogs (October 30, 1980): } \\
\hline Inlet & 7.55 & 345 & 62 & 0.16 & 0.026 \\
\hline Outlet & 7.48 & 420 & 73 & 0.29 & 0.018 \\
\hline \multicolumn{6}{|c|}{ Pentwater Marsh (November 18, 1980): } \\
\hline Inlet (South Branch) & 7.74 & 265 & 14.0 & 0.18 & 0.015 \\
\hline Inlet (North Branch) & 7.77 & 260 & 18.5 & 0.03 & 0.017 \\
\hline Outlet & 7.72 & 235 & 12.5 & 0.05 & 0.010 \\
\hline
\end{tabular}

$\mathrm{TDP}=$ total dissolved phosphorus.

\section{ACCRETION RATES OF SEDIMENTS}

\section{Methods}

Plastic tubes were used to core bottom sediments from eight locations within the three wetland systems. The locations of these cores and their properties are summarized in Table II and in Fig. 1. These cores were returned to the laboratory in the plastic tubes and frozen. The solid material was then extruded from the tube and sawed into $2-\mathrm{cm}$ increments. These sediments wafers were then oven-dried at $105^{\circ} \mathrm{C}$ and weighed to obtain the total mass distribution.

For determination of the activities of ${ }^{137} \mathrm{Cs}$, dried core sections were packaged in plastic Petri dishes (5.1 cm O.D.) and counted on a large, 7.8 $\mathrm{cm} \times 12.7 \mathrm{~cm}, \mathrm{NaI}$ gamma detector coupled to a multichannel analyzer. Details of the method are provided by Robbins and Edgington (1975) and Robbins (1978). ${ }^{40} \mathrm{~K}$ is also detected by the analytical system along with ${ }^{137} \mathrm{Cs} .{ }^{40} \mathrm{~K}$ exists in fixed ratio to total $\mathrm{K}$ and is therefore a good indicator of total $\mathrm{K}$. Because of the low activities of these isotopes in the samples, long counting times (the order of several days) were required to obtain adequate statistics. As the efficiency of the detector was not accurately determined for the entire set of samples, values for the activities are reported in counts per minute per gram. 
For determination of the activity of ${ }^{210} \mathrm{~Pb}$, a $2-\mathrm{g}$ subsample from each section of the core was placed in a small beaker to which $20 \mathrm{ml}$ of concentrated $\mathrm{HCl}$ was added plus a $1-\mathrm{ml}$ spike of ${ }^{208} \mathrm{Po}\left(40\right.$ d.p.m. $\left.\mathrm{ml}^{-1}\right)$. The ${ }^{208} \mathrm{Po}$ serves as a means of determining the absolute activity of ${ }^{210} \mathrm{Po}$ which is assumed to be in secular equilibrium with ${ }^{210} \mathrm{~Pb}$. The mixture of sample, spike and acid was shaken slowly in a bath maintained at $90^{\circ} \mathrm{C}$ for $8 \mathrm{hr}$.

\section{TABLE II}

Summary of sediment core data (see Fig. 1 for locations)

\begin{tabular}{lll}
$\begin{array}{l}\text { Core } \\
\text { No. }\end{array}$ & Location description & $\begin{array}{l}\text { Compression } \\
(\%)\end{array}$ \\
\hline \multicolumn{2}{c}{ Pentwater: } & \\
1 & sedge meadow, 7 m from South Channel & 22 \\
2 & river bottom, Southern Channel & 26 \\
3 & marsh edge at outlet pond & 50 \\
4 & cattail, 2 m from North Channel & 32 \\
5 & North Channel bank, inside of bend & 32 \\
6 & North Channel bank, outside of bend & 11 \\
& & \\
& Cranberry: & 59 \\
7 & inlet, stream delta, forested & 25 \\
8 & outlet, flood-plain, forested & \\
\hline
\end{tabular}

During this period small $(21 \mathrm{ml})$ additions of concentrated $(30 \%) \mathrm{H}_{2} \mathrm{O}_{2}$ were added to accelerate destruction of organic matter. Following this extraction period, the mixture was filtered through $0.45-\mu \mathrm{m}$ filter, the filtrant adjusted to an approximate final volume of $50 \mathrm{ml}$. with distilled water to which was added $1 \mathrm{~g}$ ascorbic acid (to prevent precipitation of $\mathrm{Fe}$ and concurrent scavenging of Po). The solution was adjusted to $\mathrm{pH} 1.5$ by small additions of concentrated ammonium hydroxide. The $\mathrm{pH}$ adjusted solutions were added to small $(250 \mathrm{ml})$ wide-mouth polyethylene bottles containing a 3.8-cm diameter silver disc covered on one side with Mylar ${ }^{\circledR}$ tape. For $\sim 8 \mathrm{hr}$. the bottle containing the disc lying on the bottom with polished face upwards and solution were gently agitated in a shaker bath at $90^{\circ} \mathrm{C}$. During this period the atoms of ${ }^{210} \mathrm{Po}$ and the spike $\left({ }^{208} \mathrm{Po}\right)$ are transferred to and spontaneously plated on the silver disc. Efficiency of plating is generally better than $90 \%$. However, because of the addition of the spike it is not necessary to determine the actual plating efficiency. Following plating of the sample, the discs were removed from the bottles, rinsed in distilled water, dried with ethanol and counted by means of a conventional alpha spectroscopy system. This system includes a high-resolution $(<20 \mathrm{keV}$ at $5.3 \mathrm{MeV})$ surface barrier detector connected to a 2048-channel (Nuclear Data $\left.{ }^{\circledR} 100\right)$ multichannel analyzer. The peaks due to ${ }^{210} \mathrm{Po}(5.33$ 
$\mathrm{MeV})$ and to ${ }^{208} \mathrm{Po}(5.11 \mathrm{MeV})$ are easily resolved by the systems. With respect to the Po isotopes the system is essentially background free. Also there is essentially no contamination of the ${ }^{208} \mathrm{Po}$ spike with ${ }^{210}{ }^{10} \mathrm{Po}\left({ }^{210} \mathrm{Po} /\right.$ ${ }^{208} \mathrm{Po}<0.005$ ). Additional details of the method are to be found in Robbins and Edgington (1975) and Robbins (1978).

\section{Discussion}

In order to establish a geochronology for a given core we use the simplest set of assumptions providing a self-consistent description of the data. For ${ }^{210} \mathrm{~Pb}$ this principle implies the following restrictive assumptions*: (1) the rate of supply (flux) of ${ }^{210} \mathrm{~Pb}$ to the site (of the core) is constant; (2) the rate of accretion is constant; and (3) the isotope does not move around in the core (no diffusion, no physical disturbance). Under these conditions the expected activity of excess ${ }^{210} \mathrm{~Pb}$ in a layer of age $t$ (yr. B.P.) is given by:

$A=A(0) \exp (-\lambda t)$

where $A(0)$ is the excess activity at the surface (in units of d.p.m. $\mathrm{g}^{-1}$ ); and $\lambda$ is the radioactive decay constant $=0.69315 / 22.26=0.0311$ yr. $^{-1}$. To re-express eq. 1 in terms of sediment depth, a relation between depth and time must be developed. Because of the high and highly variable water content of these porous and easily compressible materials, the linear measure of depth $(\mathrm{cm})$ is subject to considerable uncertainties as well as certain misinterpretations (see Table II). Apart from naturally occurring compaction there is significant compression of the cores during insertion of the coring tubes. The proper invariant is the dry weight of sediment per unit area within each interval $\left(\mathrm{g} \mathrm{cm}^{-2}\right)$. With the depth expressed in units of cumulative dry weight $(m)$ and the sedimentation rate $(r)$ expressed in units of $g$ dryweight material $\mathrm{cm}^{-2} \mathrm{yr}^{-1}$, the relation between age $t$ and depth is $t=$ $m / r$ so that eq. 1 becomes:

$A=A(0) \exp (-\lambda m / r)$

It is further assumed that the activity of ${ }^{210} \mathrm{~Pb}$ supported by in situ Ra decay is constant over the length of interest so that the total ${ }^{210} \mathrm{~Pb}$ distribution is given by:

$A_{\mathrm{T}}=\left[A_{\mathrm{T}}(0)-A_{\mathrm{f}}\right] \exp (-\lambda m / r)+A_{\mathrm{f}}$

where $A_{\mathrm{f}}$ is activity of supported ${ }^{210} \mathrm{~Pb}$; and $A_{\mathrm{T}}(0)$ is the total activity at the surface. This equation expresses the expected relation between observables $A_{\mathrm{T}}$ and $m$. If $A_{\mathrm{f}}$ is determined independently then an unweighted linear least-squares fit of:

$\ln \left(A_{\mathbf{T}}-A_{\mathbf{f}}\right)$ vs. $m$

*This is the CA (constant activity model) described by Robbins (1978) which is equivalent to the CIC model used by Appleby and Oldfield (1978). 
provides a best value of the slope $=-\lambda / r$ and an estimate of the sedimentation rate:

$r=-\lambda /($ slope $)$

A computer program was written which provides both values of the slope and an uncertainty based on $90 \%$ confidence limits.

Analysis of the ${ }^{137} \mathrm{Cs}$ profiles is based on the assumption that: (1) transfer of fallout from the air-water interface to the sediment-water interface is instantaneous (i.e. there is no external integration of inputs); (2) direct atmospheric transfer is in fact the only source of the radionuclide; and (3) ${ }^{137} \mathrm{Cs}$ is not mobile within the deposit. If $F(t)$ is the atmospheric flux (d.p.m. $\mathrm{cm}^{-2} \mathrm{yr}^{-1}$ ) at time $t$ in the past then the flux to the core is taken to be $f(t)=k F(t)$ where $k$ depends on location but not on time. The activity of the layer deposited at time $t$ was $f(t) / r$ (d.p.m. $\mathrm{g}^{-1}$ ), while the current activity of the layer (as of the counting date) is $[f(t) / r] \exp \left(-\lambda^{\prime} m / r\right)$ where $\lambda^{\prime}$ is the radioactive decay constant $\left(\lambda^{\prime}=0.6932 / 30.0=0.0231 \mathrm{yr}^{-1}\right)$. In the interval from $m_{1}$ to $m_{2}$ the measured activity is then the average of the decay-corrected activities of individual layers or,

$A\left(m_{1}, m_{2}\right)=k /\left(m_{1}-m_{2}\right) \int_{m_{1}}^{m_{2}}[F(m / r) / r] \exp \left(-\lambda^{\prime} m / r\right) \mathrm{d} m$

This equation relates the observed activity to the depth and to the atmospheric flux which is well known. Only two parameters are undetermined, the sedimentation rate $(r)$ and the ratio $(k)$ of the sediment flux to the atmospheric flux. Note that because of sediment focusing (see Robbins, 1980) the value of $k$ can be greater than 1 in some (especially large) water bodies. A computer program was written to obtain the best values for $k$ and $r$ using ${ }^{137} \mathrm{Cs}$ deposition data as reported by Gustafson et al. (1970) and H.A.S.L. (1977). (Note that ${ }^{137} \mathrm{Cs}$ fluxes are in part constructed from nearly three decades of ${ }^{90} \mathrm{Sr}$ deposition data for sampling within the Great Lakes watershed. ${ }^{137} \mathrm{Cs}$ and ${ }^{90} \mathrm{Sr}$ are deposited essentially in a fixed ratio.)

Pentwater: South Branch No. 1

The data for this core are provided in Table III. The distribution of ${ }^{210} \mathrm{~Pb}$ shown in Fig. 13 is essentially exponential over the length of the core. If a significant activity of supported ${ }^{210} \mathrm{~Pb}$ were present, the observed distribution would tail off toward the bottom of the core. That it does not is presumptive evidence for a level of supported ${ }^{210} \mathrm{~Pb}$ considerably less than observed in the deepest section of the core (i.e. 4.95 d.p.m. $\mathrm{g}^{-1}$ ). The leastsquares regression line shown corresponds to a sedimentation rate of $0.15 \pm$ $0.02 \mathrm{~g} \mathrm{~cm}^{-2} \mathrm{yr}^{-1}$. This value is calculated assuming $A_{\mathrm{f}}$ (in eq. 3 ) is zero. The sensitivity of the calculated accretion rate to the choice for $A_{\mathrm{f}}$ is illustrated in Table IV. It can be seen that a zero value of $A_{\mathrm{f}}$ maximizes the 
TABLE III

Distribution of ${ }^{137} \mathrm{Cs},{ }^{40} \mathrm{~K}$ and ${ }^{210} \mathrm{~Pb}$ in the South Branch (bank) Core (No. 1)

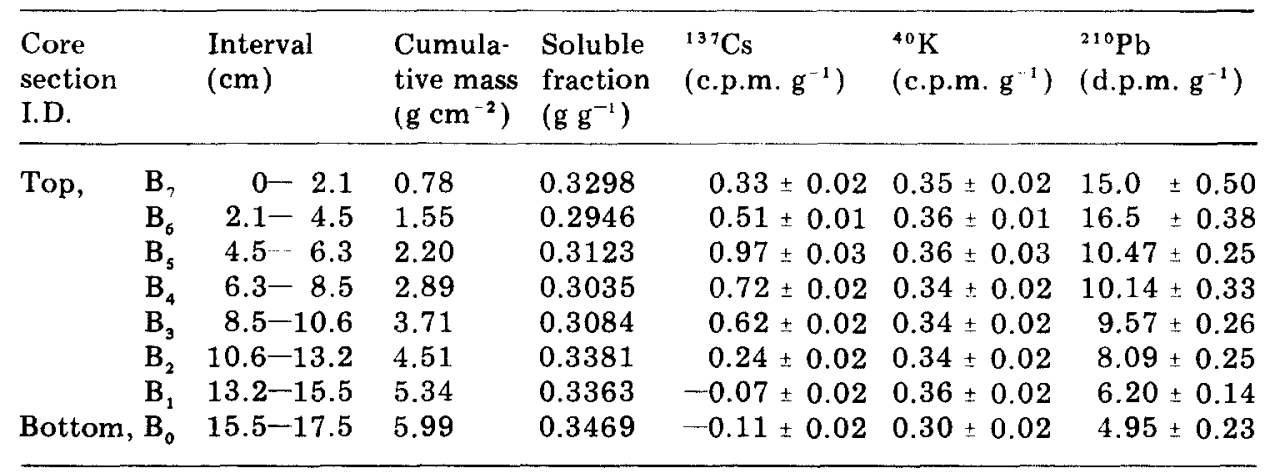

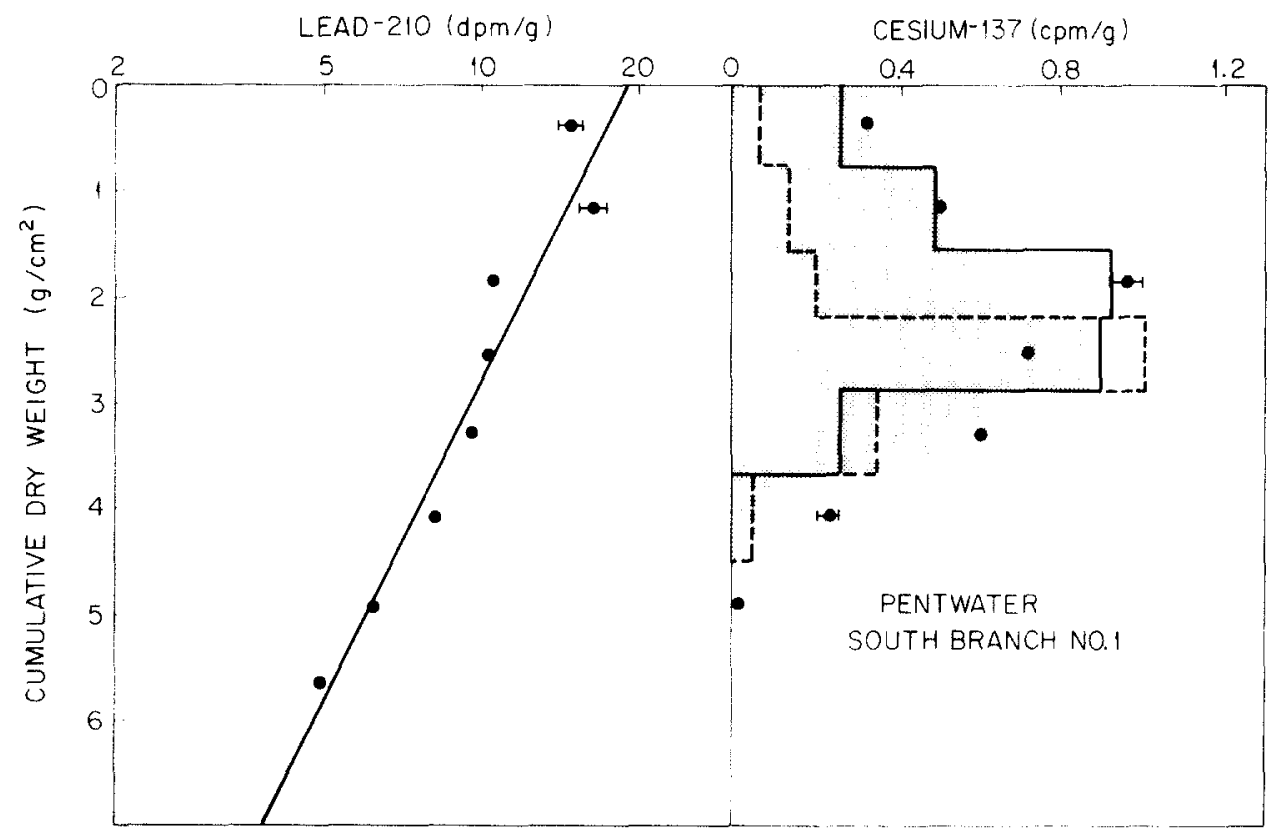

Fig. 13. Distribution of ${ }^{210} \mathrm{~Pb}$ and ${ }^{137} \mathrm{Cs}$ in the Pentwater South Branch Core No. 1. The dashed histogram (right panel) shows the distribution of ${ }^{13} \mathrm{Cs}$ expected from direct atmospheric fallout. The solid-line histogram is the distribution expected if the inputs are externally integrated (see text).

degree of correlation and minimizes the fractional error in estimating the accretion rate. This choice is also consistent with the high organic content of the core. Supported ${ }^{210} \mathrm{~Pb}$ is primarily associated with inorganic mineral phases. Over a range of values of $A_{\mathrm{f}}$ from 0.0 to $\sim 2.0$ d.p.m. $\mathrm{g}^{-1}$ the quality of the fit does not change significantly although the calculated accretion 
TABLE IV

Dependence of the calculated sedimentation rate on the assumed level of supported ${ }^{210} \mathrm{~Pb}-$ Core: Pentwater, South Branch No. 1

\begin{tabular}{lll}
\hline $\begin{array}{l}\text { Supported } \\
\text { activity } \\
\text { (d.p.m. }\end{array}$ & $\begin{array}{l}\text { Calculated } \\
\text { sedimentation } \\
\text { rate } \\
\left(\mathrm{g} \mathrm{cm}^{-2} \mathrm{yr}^{-1}\right)\end{array}$ & $|r|^{*}$ \\
\hline 0 & $0.146 \pm 0.020$ & 0.967 \\
1 & $0.129 \pm 0.017$ & 0.967 \\
2 & $0.111 \pm 0.015$ & 0.965 \\
3 & $0.093 \pm 0.016$ & 0.960 \\
4 & $0.072 \pm 0.014$ & 0.943 \\
\hline
\end{tabular}

*Absolute value of the correlation coefficient $(N=8)$.

rate changes by $\sim 27 \%$. In the absence of independent information it is not possible to assign a more accurate value for the accretion rate. The most conservative estimate assumes that the value of $A_{\mathrm{f}}$ lies between 0 and $\sim 4$ d.p.m. $\mathrm{g}^{-1}$. In the table summarizing the accretion rates (see Table XII) the value of $A_{\mathrm{f}}$ is taken as $2.0 \pm 2.0 \mathrm{~d} . \mathrm{p.m} . \mathrm{g}^{-1}$. This leads to an estimate of $0.11 \pm 0.04 \mathrm{~g} \mathrm{~cm}^{-2} \mathrm{yr}^{-1}$ for the accretion rate and associated uncertainty. Values of the mean linear rate in this table are determined by computing:

(age of the base of the core) $=$ (cumulative mass) $/($ accretion rate)

and dividing the length of the core by this time. Thus for core $1, \Delta t=5.99$ $\left(\mathrm{g} \mathrm{cm}^{-2}\right) / 0.11\left(\mathrm{~g} \mathrm{~cm}^{-2} \mathrm{yr}^{-1}\right)=54.5 \mathrm{yr}$. The average compressed linear growth rate $=17.5(\mathrm{~cm}) / 54.5(\mathrm{yr})=.0.32 \mathrm{~cm} \mathrm{yr}^{-1}$ (corresponds to a reconstructed growth of $\left.0.41 \mathrm{~cm} \mathrm{yr} .^{-1}\right)$.

The distribution of ${ }^{137} \mathrm{Cs}$ (also shown in Fig. 13) exhibits a peak at $\sim 2.0$ $\mathrm{g} \mathrm{cm}^{-2}$ which appears to correspond to the peak in fallout. The dashed line in the figure is the distribution expected from the model discussed above for a value of the accretion rate based on the ${ }^{210} \mathrm{~Pb}$ data $\left(0.15 \mathrm{~g} \mathrm{~cm}^{-2} \mathrm{yr}^{-1}\right)$. It can be seen that while the predicated peak location is in reasonable accord with the observed position, the theoretical profile underestimates both the spread in the observed distribution and the amount of ${ }^{137} \mathrm{Cs}$ in sediments above the peak. Failure of the simple model is not surprising in light of the experience of others in use of ${ }^{137} \mathrm{Cs}$ to date wetland deposits. Oldfield et al. (1979) found radiocesium profiles in ombrotrophic peat cores which were diffuse, extending to depths considerably greater than expected on the basis of known fallout records and independent more reliable chronological methods. They considered that radiocesium undergoes active uptake by living plants as well as diffusional migration within layers and is thus not useful as a geochronological tool. In comparison to the discrepancies observed by Oldfield et al. those in the South Branch Core are minor and 
warrant further consideration. Elevated surface concentrations of the isotope could easily arise from indirect and delayed transfers from other parts of the system. This could occur if a significant portion of the radiocesium reaching the site was derived from an external reservoir (either watershed, or resuspended stream deposits) which integrates the inputs. Consider an extreme case in which the only Cs reaching the site is the result of prior storage in an integrating reservoir. If the residence time of the radionuclide in the reservoir is $T_{\mathrm{r}}$ then the flux reaching the location is given by a term proportional to $F_{\mathrm{r}}$ defined as:

$\mathrm{d} F_{\mathrm{r}} / \mathrm{d} t=F^{\prime} \lambda--\left(\lambda+\lambda_{\mathrm{r}}\right) F_{\mathrm{r}}$

where $F$ is the atmospheric flux defined above; and $\lambda_{\mathrm{r}}=1 / T_{\mathrm{r}}$. The expected distribution is then obtained by substituting the solution of eq. 7 for $F^{\prime}$ into eq. 6. The solid curve shown in Fig. 13 is the distribution expected if the accretion rate is kept unchanged at the value determined from ${ }^{210} \mathrm{~Pb}$ while the best value of the reservoir integration time is determined via least-squares minimization. Under such conditions, the optimal integration time is $\sim 5 \mathrm{yr}$. It can be seen that considerable improvement in the theoretical representation is obtained by introduction of this concept. By allowing both the integration time and sedimentation rate to vary, a theoretical distribution is obtained as shown in Fig. 13 (shaded area) for $r=0.18 \mathrm{~g} \mathrm{~cm}^{-2} \mathrm{yr}^{-1}$ and $T_{\mathrm{r}}=$ $10.0 \mathrm{yr}$.

Pentwater: South Branch No. 2

The data for this core are provided in Table V. The core consists largely of fine to medium sand with very little organic matter. Analysis of the top

\section{TABLE V}

Distribution of ${ }^{137} \mathrm{Cs}$ and ${ }^{40} \mathrm{~K}$ in the South Branch (river bottom) core (No. 2)

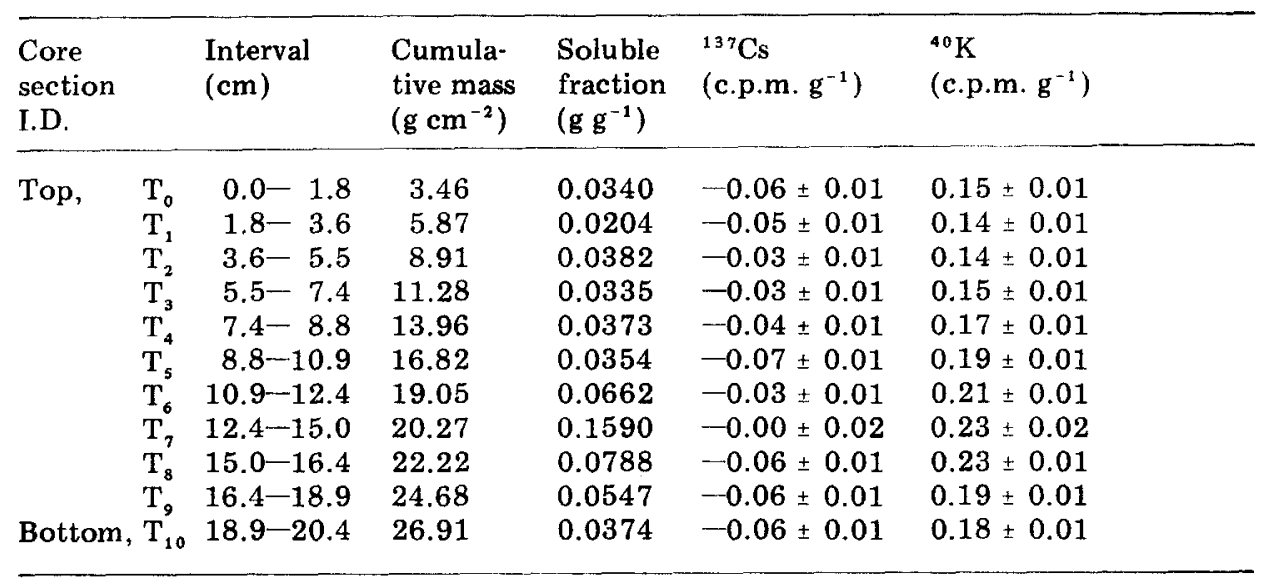


section for ${ }^{210} \mathrm{~Pb}$ showed no ${ }^{210} \mathrm{~Pb}\left(0.0 \pm 1\right.$ d.p.m. $\left.\mathrm{g}^{-1}\right) \cdot{ }^{137} \mathrm{Cs}$ is undetectable in all sections of the core. ${ }^{40} \mathrm{~K}$ is a good indicator of the amount of finegrained inorganic (non-quartz) material (clay/feldspars) present in the deposits. Cores may be conveniently differentiated by the ${ }^{40} \mathrm{~K}$ content and acid-soluble fraction. The latter quantity is a measure both of the organic carbon content plus other readily leachable phases including carbonates, $\mathrm{Fe} / \mathrm{Mn}$ compounds and certain other minerals. In Fig. 14 it can be seen that the South Branch Core is low in terms of the soluble fraction and intermediate in terms of ${ }^{40} \mathrm{~K}$. In contrast, Bridge Side core No. 3 is particularly low in ${ }^{40} \mathrm{~K}$ and has a high soluble fraction. This core consists primarily of organic matter and is low in both quartz and $\mathrm{K}$-bearing minerals. In contrast the South Branch core No. 1 is high in terms of the acid-soluble fraction (primarily organic carbon) and in the amount of K-bearing minerals. The tight grouping of points in each core reflects the minor changes in gross constituents downcore. Major stratigraphic changes in cores can play havoc with the interpretation of radionuclide profiles.

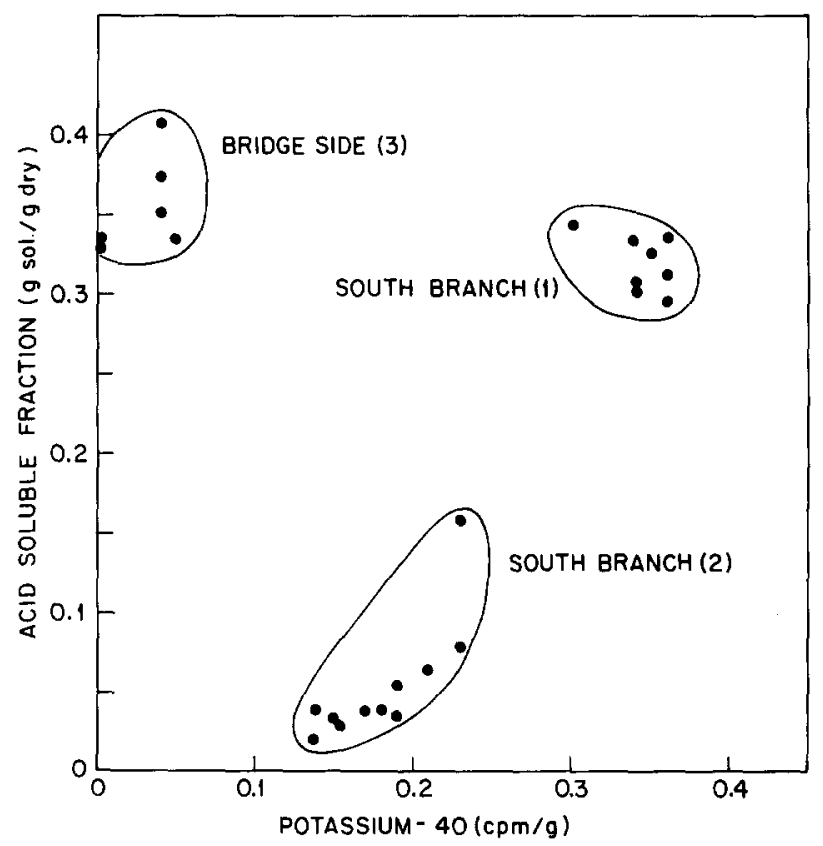

Fig. 14. Discrimination of core materials in terms of the soluble fraction and ${ }^{40} \mathrm{~K}$. The core with low soluble fraction values (high sand) and intermediate ${ }^{40} \mathrm{~K}$ levels (clay minerals) contains negligible ${ }^{137} \mathrm{Cs}$ and ${ }^{210} \mathrm{~Pb}$.

Pentwater: Bridge Side No. 3

The data for this core are provided in Table VI. The distributions of ${ }^{210} \mathrm{~Pb}$ and ${ }^{137} \mathrm{Cs}$ are shown in Fig. 15. In this core the activity of supported $\mathrm{Pb}$ 
appears to be 0.97 d.p.m. $\mathrm{g}^{-1}$. Using this value of $A_{\mathrm{f}}$, the calculated accretion rate is $0.0098 \pm 0.0026 \mathrm{~g} \mathrm{~cm}^{-2} \mathrm{yr}^{-1}$. The solid line shown in the figure is the predicted distribution of ${ }^{210} \mathrm{~Pb}$ based on this accretion rate $(r=0.97$ for $n=4)$. In the summary table the value of $A_{\mathrm{f}}$ is taken to be $0.97 \pm 0.5$ d.p.m. $\mathrm{g}^{-1}$.

TABLE VI

Distribution of ${ }^{137} \mathrm{Cs},{ }^{40} \mathrm{~K}$ and ${ }^{210} \mathrm{~Pb}$ in the Bridge Side Core (No. 3)

\begin{tabular}{|c|c|c|c|c|c|c|c|}
\hline $\begin{array}{l}\text { Core } \\
\text { section } \\
\text { I.D. }\end{array}$ & & $\begin{array}{l}\text { Interval } \\
(\mathrm{cm})\end{array}$ & $\begin{array}{l}\text { Cumula- } \\
\text { tive mass } \\
\left(\mathrm{g} \mathrm{cm}^{-2}\right)\end{array}$ & $\begin{array}{l}\text { Soluble } \\
\text { fraction } \\
\left(\mathrm{g} \mathrm{g}^{-1}\right)\end{array}$ & $\begin{array}{l}{ }^{137} \mathrm{Cs} \\
\left(\text { c.p.m. } \mathrm{g}^{-1}\right)\end{array}$ & 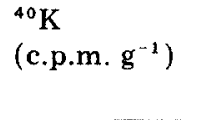 & $\begin{array}{l}{ }^{210} \mathrm{~Pb} \\
\text { (d.p.m. } \mathrm{g}^{-1} \text { ) }\end{array}$ \\
\hline \multirow[t]{6}{*}{ Top, } & $\mathrm{B}_{5}$ & $0.0-3.0$ & 0.28 & 0.4065 & $1.20 \pm 0.07$ & $0.04 \pm 0.08$ & $13.75 \pm 0.45$ \\
\hline & $\mathrm{B}_{4}$ & $3.0-5.6$ & 0.54 & 0.3392 & $0.27 \pm 0.06$ & $-0.05 \pm 0.06$ & $6.70 \pm 0.31$ \\
\hline & $\mathrm{B}_{3}$ & $5.6-7.8$ & 0.76 & 0.3716 & $0.23 \pm 0.05$ & $0.04 \pm 0.05$ & $5.11 \pm 0.25$ \\
\hline & $\mathrm{B}_{2}$ & $7.8-9.8$ & 1.02 & 0.3316 & $0.00 \pm 0.05$ & $-0.02+0.05$ & $2.00 \pm 0.11$ \\
\hline & $B_{1}$ & $9.8-12.1$ & 1.27 & 0.3522 & $-0.01 \pm 0.04$ & $0.05 \pm 0.05$ & $0.96 \pm 0.08$ \\
\hline & $B_{0}$ & $12.1-14.2$ & 1.51 & 0.3508 & $-0.04 \pm 0.03$ & $0.04 \pm 0.03$ & $0.98 \pm 0.07$ \\
\hline
\end{tabular}

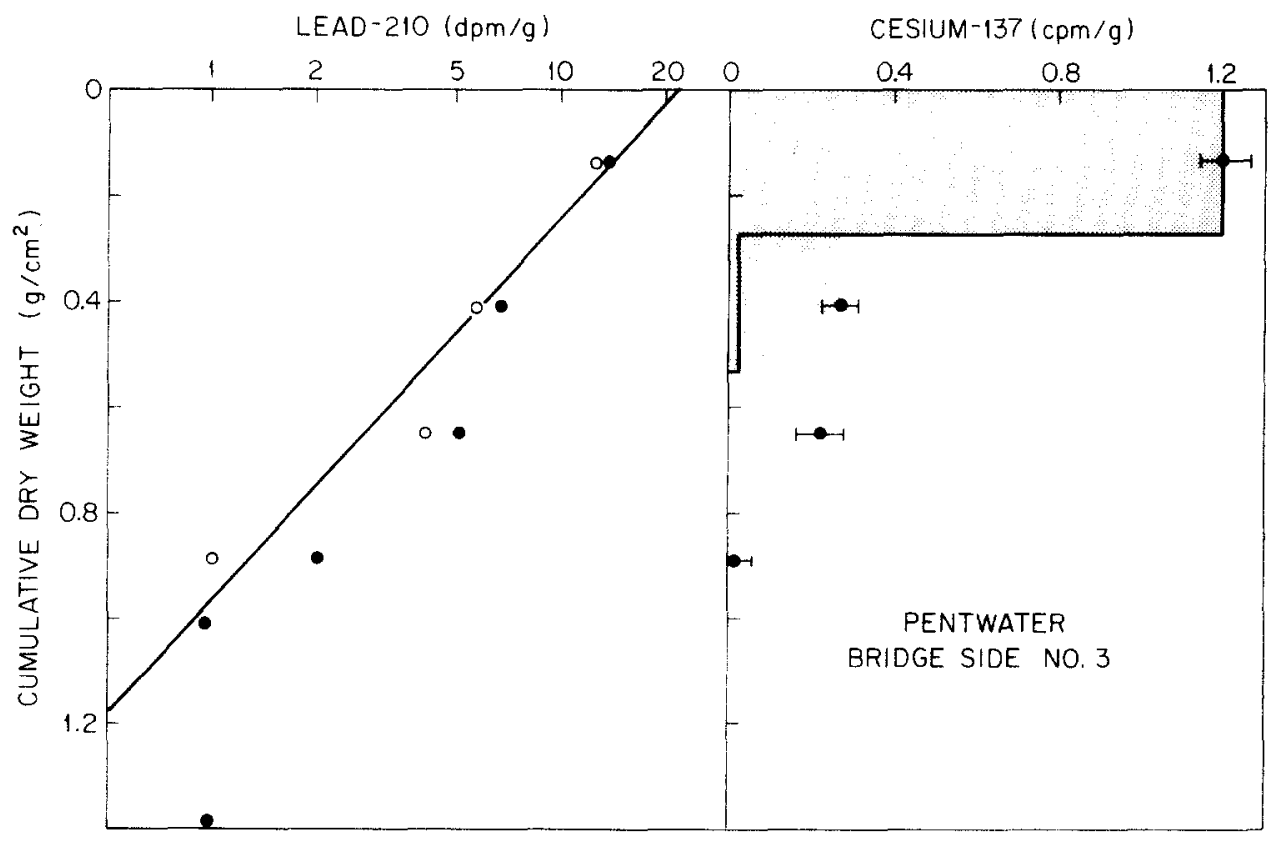

Fig. 15. Distribution of total $(\bullet)$ and excess $(0){ }^{210} \mathrm{~Pb}$ and ${ }^{137} \mathrm{Cs}$ in the Pentwater Bridge Side Core No. 3. The histogram is the expected distribution of ${ }^{137} \mathrm{Cs}$ based on the ${ }^{210} \mathrm{~Pb}$ sedimentation rate. Some small activity of ${ }^{137} \mathrm{Cs}$ occurs in a lower section, suggesting slight mobility of this isotope. 
As seen in Fig. 15 (right panel) most of the ${ }^{137} \mathrm{Cs}$ is confined to the upper layer. This result is predicted on the basis of the ${ }^{210} \mathrm{~Pb}$ accretion rate. The solid line in the figure shows the distribution predicted for a system integration time of zero. Essentially an identical theoretical profile is obtained if the integration time is taken as $10 \mathrm{yr}$. Allowing the rate to vary produces the distribution shown as the shaded area in the figure. This distribution corresponds to a slightly higher apparent accretion rate of $0.0156 \mathrm{~g} \mathrm{~cm}^{-2}$ yr. $^{-1}$. Even so, slight but significant activity between 0.54 and $0.76 \mathrm{~g} \mathrm{~cm}^{-2}$ is not accounted for by the model either by increasing the sedimentation rate within the limits of uncertainty or by introducing the system integration concept. Hence, there appears to be some slight mobility of the isotope in this core, assuming the validity of the ${ }^{210} \mathrm{~Pb}$ chronology.

Pentwater: North Branch No. 4

Data for this core are provided in Table VII. The amount of supported ${ }^{210} \mathrm{~Pb}$ appears to be determinable in a straightforward way, as the activity in the bottom three sections is essentially constant ( $3.77 \mathrm{~d} . \mathrm{p} . \mathrm{m} . \mathrm{g}^{-1}$ average) although unusually high. The accretion rate using this average value is 0.049 $\pm 0.01 \mathrm{~g} \mathrm{~cm}^{-2} \mathrm{yr}^{-1}$. However, note that in this core there is a systematic variation in the acid-soluble fraction. From a value of 0.38 in the top section it decreases monotonically with increasing depth to 0.25 in the section at $3.73-4.56 \mathrm{~g} \mathrm{~cm}^{-2}$. However, in the bottom two sections, the soluble fraction increases significantly. Thus the apparent constancy of the activity of ${ }^{210} \mathrm{~Pb}$ expressed on total weight basis may be an artifact of increased solubility of materials in the deeper sections. How can a valid accretion rate be inferred in the presence of systematic variations in gross composition of core material? Without additional characterization there is no entirely reliable way. But under certain restrictive assumptions it is possible to build a selfconsistent picture. Suppose that excess ${ }^{210} \mathrm{~Pb}$ goes completely into solution

\section{TABLE VII}

Distribution of ${ }^{137} \mathrm{Cs},{ }^{40} \mathrm{~K}$ and ${ }^{210} \mathrm{~Pb}$ in the North Branch Pentwater Core (No. 4)

\begin{tabular}{|c|c|c|c|c|c|c|c|}
\hline $\begin{array}{l}\text { Core } \\
\text { section } \\
\text { I.D. }\end{array}$ & & $\begin{array}{l}\text { Interval } \\
\text { (cm) }\end{array}$ & $\begin{array}{l}\text { Cumula- } \\
\text { tive mass } \\
\left(\mathrm{g} \mathrm{cm}^{-2}\right)\end{array}$ & $\begin{array}{l}\text { Soluble } \\
\text { fraction } \\
\left(g^{-1}\right)\end{array}$ & $\begin{array}{l}{ }^{137} \mathrm{Cs} \\
\left.\text { (c.p.m. } \mathrm{g}^{-1}\right)\end{array}$ & $\begin{array}{l}{ }^{40} \mathrm{~K} \\
\text { (c.p.m. } \mathrm{g}^{-1} \text { ) }\end{array}$ & $\begin{array}{l}{ }^{210} \mathrm{~Pb} \\
\left.\text { (d.p.m. } \mathrm{g}^{-1}\right)\end{array}$ \\
\hline \multirow[t]{6}{*}{ Top, } & B & $0.0-2.8$ & 0.94 & 0.3751 & $0.40 \pm 0.01$ & $0.24 \pm 0.01$ & $8.24 \pm 0.27$ \\
\hline & B & $2.8-5.5$ & 1.81 & 0.2836 & $0.08 \pm 0.01$ & $0.28 \pm 0.01$ & $6.27 \pm 0.17$ \\
\hline & B & $5.5-8.2$ & 2.88 & 0.2787 & $-0.06 \pm 0.02$ & $0.32 \pm 0.02$ & $5.55 \pm 0.22$ \\
\hline & $\mathrm{B}_{3}$ & $8.2-10.5$ & 3.73 & 0.2588 & $-0.06 \pm 0.02$ & $0.29 \pm 0.02$ & $4.45 \pm 0.15$ \\
\hline & $\mathbf{R}$ & $10.5-12.5$ & 4.56 & 0.2456 & $-0.06 \pm 0.02$ & $0.28 \pm 0.02$ & $3.85 \pm 0.18$ \\
\hline & & $12.5-14.6$ & 5.16 & 0.3214 & $-0.06 \pm 0.02$ & $0.18 \pm 0.02$ & $3.98 \pm 0.18$ \\
\hline Bottor & $\mathrm{B}_{0}$ & $14.6-16.9$ & 5.69 & 0.3360 & $-0.03 \pm 0.02$ & $0.13 \pm 0.03$ & $3.47 \pm 0.16$ \\
\hline
\end{tabular}


on extraction and that the only reason for variations in fraction soluble is changing dilution of the ${ }^{210} \mathrm{~Pb}$ carrier material by inert constituents (such as sand). If this is the only process affecting the activity of ${ }^{210} \mathrm{~Pb}$ downcore except for radioactive decay, then the activity on a weight soluble basis may be used to determine the age of core layers. On the basis of the "renormalized" ${ }^{210} \mathrm{~Pb}$ data, the accretion rate is $0.14 \pm 0.03 \mathrm{~g} \mathrm{~cm}^{-2} \mathrm{yr}^{-1}$. Values of accretion rates for all cores based on renormalized ${ }^{210} \mathrm{~Pb}$ data are presented in Table XIII. In cases where there is little downcore variation in the soluble fraction there is essentially no difference in accretion rates calculated by the two methods. In the case of this core (No. 4) the value based on unnormalized data is considerably lower $\left(0.10 \mathrm{~g} \mathrm{~cm}^{-2} \mathrm{yr}^{-1}\right)$. In the summary table (Table XIII), a value of $1.8 \pm 1.8 \mathrm{~d} . \mathrm{p} . \mathrm{m} . \mathrm{g}^{-1}$ is used for supported ${ }^{210} \mathrm{~Pb}$. This uncertainty reflects the lack of knowledge as to whether ${ }^{210} \mathrm{~Pb}$ activities in the lower two core sections are representative of supported levels or not.

In this core ${ }^{137} \mathrm{Cs}$ occurs primarily in the upper section. If the accretion rate is correctly given as $0.14 \mathrm{~cm} \mathrm{yr}^{-1}$ significant ${ }^{137} \mathrm{Cs}$ activity should be found in the upper three sections. As the range of uncertainty is large in the estimate of the accretion rate, the Cs profile can be said to be consistent with the ${ }^{210} \mathrm{~Pb}$ data but to select toward the lower accretion rate. Application of the model to the ${ }^{137} \mathrm{Cs}$ profile yields a sedimentation rate of $0.04 \mathrm{~g}$ $\mathrm{cm}^{-2} \mathrm{yr}^{-1}$ for an integration time of zero and $0.06 \mathrm{~g} \mathrm{~cm}^{-2} \mathrm{yr}^{-1}$ for an integration time of $\sim 10 \mathrm{yr}$.

\section{Pentwater: North Branch No. 5}

Data for this core are given in Table VIII. In this core there is a systematic six-fold decrease in the amount of acid-soluble material with increasing depth. Because of this major variability, it would be misleading to obtain a sedimentation rate estimate based on unnormalized ${ }^{210} \mathrm{~Pb}$ activities. Nor-

\section{TABLE VIII}

Distribution of ${ }^{137} \mathrm{Cs},{ }^{40} \mathrm{~K}$ and ${ }^{210} \mathrm{~Pb}$ in the North Branch Pentwater Core (No. 5)

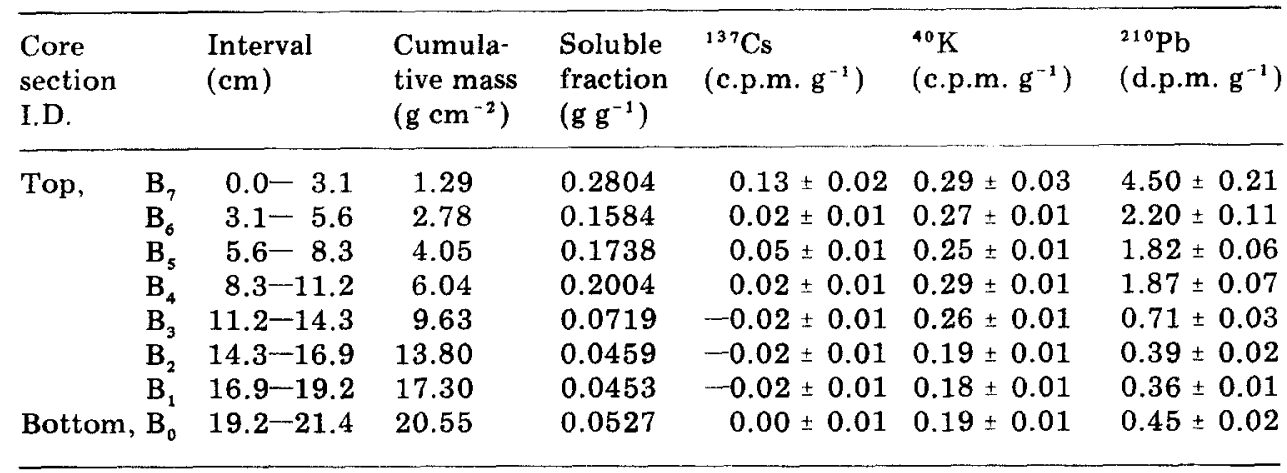


malized ${ }^{210} \mathrm{~Pb}$ activities decrease more or less exponentially to a constant level of $\sim 8.3$ d.p.m. $\mathrm{g}^{-1}$ sol. (average in the bottom three sections). Using this average, the calculated accretion rate is $0.10 \pm 0.03 \mathrm{~g} \mathrm{~cm}^{-2} \mathrm{yr}^{-1}$. In the summary table (Table XIII) the value is taken as $1.8 \pm 1.8 \mathrm{~d} . \mathrm{p} . \mathrm{m} . \mathrm{g}^{-1} \mathrm{sol}$. which leads to a considerably larger value for the accretion rate $(0.47 \pm 0.22$ $\mathrm{g} \mathrm{cm}^{-2} \mathrm{yr}^{-1}$ ) as well as larger uncertainty.

The activity of ${ }^{137} \mathrm{Cs}$ in this core is extremely low often bordering on the limits of detectability. Significant activity is seen in the section between 4.05 and $6.04 \mathrm{~g} \mathrm{~cm}^{-2}$ (mean depth, $5.0 \mathrm{~g} \mathrm{~cm}^{-2}$ ) which should correspond to an onset of ${ }^{137} \mathrm{Cs}$ in 1955 or $\sim 25 \mathrm{yr}$. B.P. If there is no mobility of the isotope this correspondence implies an accretion rate of about 5.0/25 = $0.2 \mathrm{~g} \mathrm{~cm}^{-2} \mathrm{yr}^{-1}$. Because the data for Cs are so marginal, model fits are without much significance. But the distribution of Cs supports the lower sedimentation rate and very limited mobility of the isotope in this and in other cores in deeper sections.

\section{Pentwater: North Branch No. 6}

In this core the soluble fraction is essentially constant over the entire length and there is virtually no ${ }^{40} \mathrm{~K}$ present (Table IX). Activities in the lower four sections are taken to indicate supported ${ }^{210} \mathrm{~Pb}$ levels $(1.34$ d.p.m. $\mathrm{g}^{-1}$ average). The model accretion rate is $0.0053 \pm 0.0029 \mathrm{~g} \mathrm{~cm}^{-2} \mathrm{yr}^{-1}$. Normalized ${ }^{210} \mathrm{~Pb}$ activities yield essentially the same accretion rate. For this accretion rate, ${ }^{137} \mathrm{Cs}$ is expected to be confined to the upper section of core. However, a significant amount is found in two lower sections. An independent fit of the model to the ${ }^{137} \mathrm{Cs}$ data yields a much higher accretion rate: $0.018 \mathrm{~g} \mathrm{~cm}^{-2} \mathrm{yr}^{-1}\left(T_{\mathrm{R}}=0\right)$ and $0.023 \mathrm{~g} \mathrm{~cm}^{-2} \mathrm{yr}^{-1}\left(T_{\mathrm{R}}=10 \mathrm{yr}\right.$. $)$. Uncertainties in the ${ }^{210} \mathrm{~Pb}$-derived sedimentation rates, while large, are not sufficient to account for the penetration of ${ }^{137} \mathrm{Cs}$. In this core there is evidently some migration of the isotope if the ${ }^{210} \mathrm{~Pb}$-based accretion rates are close to being correct.

\section{TABLE IX}

Distribution of ${ }^{137} \mathrm{Cs},{ }^{40} \mathrm{~K}$ and ${ }^{210} \mathrm{~Pb}$ in the North Branch Pentwater Core (No. 6)

\begin{tabular}{|c|c|c|c|c|c|c|}
\hline $\begin{array}{l}\text { Core } \\
\text { section } \\
\text { I.D. }\end{array}$ & $\begin{array}{l}\text { Interval } \\
\text { (cm) }\end{array}$ & $\begin{array}{l}\text { Cumula- } \\
\text { tive mass } \\
\left(\mathrm{g} \mathrm{cm}^{-2}\right)\end{array}$ & $\begin{array}{l}\text { Soluble } \\
\text { fraction } \\
\left(\mathrm{g} \mathrm{g}^{-1}\right)\end{array}$ & $\begin{array}{l}{ }^{137} \mathrm{Cs} \\
\left.\text { (c.p.m. } \mathrm{g}^{-1}\right)\end{array}$ & $\begin{array}{l}{ }^{40} \mathrm{~K} \\
\text { (c.p.m. } \mathrm{g}^{-1} \text { ) }\end{array}$ & $\begin{array}{l}{ }^{210} \mathrm{~Pb} \\
\left.\text { (d.p.m. } \mathrm{g}^{-1}\right)\end{array}$ \\
\hline Top, & $0.0-2.1$ & 0.42 & 0.3685 & $0.46 \pm 0.04$ & $0.09 \pm 0.04$ & $7.31 \pm 0.21$ \\
\hline 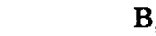 & $2.1-4.3$ & 0.66 & 0.3597 & $0.17 \pm 0.05$ & $-0.00 \pm 0.05$ & $3.75 \pm 0.13$ \\
\hline & $4.3-6.7$ & 0.87 & 0.3572 & $0.09 \pm 0.06$ & $0.10 \pm 0.06$ & $1.53 \pm 0.09$ \\
\hline B & $6.7-8.9$ & 1.11 & 0.3361 & $0.03 \pm 0.05$ & $0.02 \pm 0.05$ & $1.26 \pm 0.07$ \\
\hline B & $8.9-11.2$ & 1.36 & 0.3533 & $0.03 \pm 0.02$ & $0.03 \pm 0.03$ & $1.30 \pm 0.08$ \\
\hline B & $11.2-13.5$ & 1.62 & 0.3459 & $0.04 \pm 0.04$ & $0.08 \pm 0.05$ & $1.39 \pm 0.09$ \\
\hline Bottom, B & $13.5-15.5$ & 1.86 & 0.3635 & $0.07 \pm 0.05$ & $0.02 \pm 0.05$ & $1.41 \pm 0.06$ \\
\hline
\end{tabular}




\section{Cranberry: Inlet No. 7}

In this core there are major downcore variations in the soluble fraction (Table X). Accretion rate are based only on renormalized values (acidsoluble basis). Renormalized ${ }^{210} \mathrm{~Pb}$ activities decrease more or less exponentially with increasing depth in the core to levels of $\sim 16.7( \pm 0.1)$ d.p.m. $\mathrm{g}^{-1}$ sol. in the bottom two sections. This value for the supported ${ }^{210} \mathrm{~Pb}$ yields an accretion rate of $0.022 \pm 0.004 \mathrm{~g} \mathrm{~cm}^{-2} \mathrm{yr}^{-1}$. In the summary table (Table XIII) the value of $A_{\mathrm{f}}$ is taken to be $8.0 \pm 6.0$ d.p.m. $\mathrm{g}^{-1}$ sol. which leads to the conservative estimate for the accretion rate of $0.033 \pm 0.007 \mathrm{~g}$ $\mathrm{cm}^{-2} \mathrm{yr}^{-1}$. This rate is very consistent with that obtained from the ${ }^{137} \mathrm{Cs}$ profile. An independent fit yields $0.023 \mathrm{~g} \mathrm{~cm}^{-2} \mathrm{yr}^{-1}$ for $T_{\mathrm{r}}$ is zero and $0.028 \mathrm{~g} \mathrm{~cm}^{-2} \mathrm{yr}^{-1}$ for $T_{\mathrm{r}}=20 \mathrm{yr}$. The quality of the fit is substantially improved by introduction of the external integration process.

TABLE X

Distribution of ${ }^{137} \mathrm{Cs},{ }^{40} \mathrm{~K}$ and ${ }^{210} \mathrm{~Pb}$ in the Cranberry Inlet Core (No. 7)

\begin{tabular}{|c|c|c|c|c|c|c|}
\hline $\begin{array}{l}\text { Core } \\
\text { section } \\
\text { I.D. }\end{array}$ & $\begin{array}{l}\text { Interval } \\
(\mathrm{cm})\end{array}$ & $\begin{array}{l}\text { Cumula- } \\
\text { tive mass } \\
\left(\mathrm{g} \mathrm{cm}^{-2}\right)\end{array}$ & $\begin{array}{l}\text { Soluble } \\
\text { fraction } \\
\left(\mathbf{g} \mathbf{g}^{-1}\right)\end{array}$ & $\begin{array}{l}{ }^{137} \mathrm{Cs} \\
\left.\text { (c.p.m. } \mathrm{g}^{-1}\right)\end{array}$ & $\begin{array}{l}{ }^{40} \mathrm{~K} \\
\text { (c.p.m. } \mathrm{g}^{-1} \text { ) }\end{array}$ & $\begin{array}{l}{ }^{210} \mathrm{~Pb} \\
\left.\text { (d.p.m. } \mathrm{g}^{-1}\right)\end{array}$ \\
\hline \multirow{4}{*}{ Top, } & $0.0^{-}-2.5$ & 0.35 & 0.3818 & $1.18 \pm 0.04$ & $0.13 \pm 0.03$ & $25.45 \pm 0.76$ \\
\hline & $2.5-4.2$ & 0.65 & 0.2892 & $0.86 \pm 0.04$ & $0.10 \pm 0.04$ & $12.21 \pm 0.35$ \\
\hline & $4.2-6.5$ & 2.34 & 0.1052 & $0.03 \pm 0.02$ & $0.16 \pm 0.02$ & $2.52 \pm 0.09$ \\
\hline & $6.5-9.1$ & 4.66 & 0.0821 & $-0.05 \pm 0.01$ & $0.16 \pm 0.01$ & $1.36 \pm 0.06$ \\
\hline Bottom, $\mathrm{F}$ & $9.1--11.6$ & 6.94 & 0.1160 & $-0.05 \pm 0.01$ & $0.15 \pm 0.01$ & $1.95 \pm 0.08$ \\
\hline
\end{tabular}

\section{Cranberry: Outlet No. 8}

This core is also subject to systematic downcore decreases in the acidsoluble fraction (Table XI). From top to bottom there is roughly a fourfold reduction in the amount of soluble material. Accretion rates are calculated only for renormalized ${ }^{210} \mathrm{~Pb}$ activities. In Fig. 16 the distribution of ${ }^{210} \mathrm{~Pb}$ both on a whole-sediment basis and on an acid-soluble basis is shown. It can be seen that the curve is linearized (on a log scale) by the renormalization procedure. This lends support to the idea that the curvature is an artifact of variable dilution by inert constituents. Renormalized ${ }^{210} \mathrm{~Pb}$ appears to decrease without reaching supported levels within the length of core available. Thus the supported ${ }^{210} \mathrm{~Pb}$ would appear to be significantly less than 4.7 d.p.m. $\mathrm{g}^{-1}$ sol. (activity in the deepest section) but probably significantly higher than zero. In this summary table (Table XIII) the value and range are taken to be $3.0 \pm 1.5$ d.p.m. $\mathrm{g}^{-1}$ sol. This leads to a conservatively estimated accretion rate of $0.23 \pm 0.06 \mathrm{~g} \mathrm{~cm}^{-2} \mathrm{yr}^{-1}$. 


\section{TABLE XI}

Distribution of ${ }^{137} \mathrm{Cs},{ }^{40} \mathrm{~K}$ and ${ }^{210} \mathrm{~Pb}$ in the Cranberry Outlet Core (No. 8)

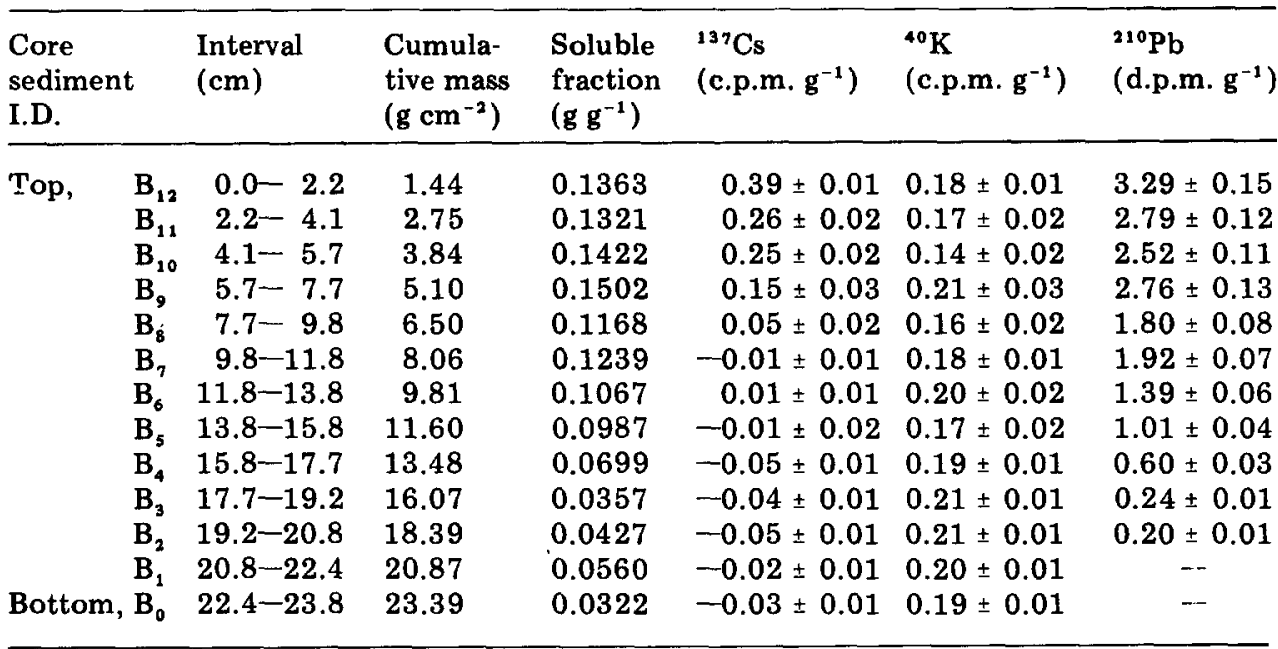

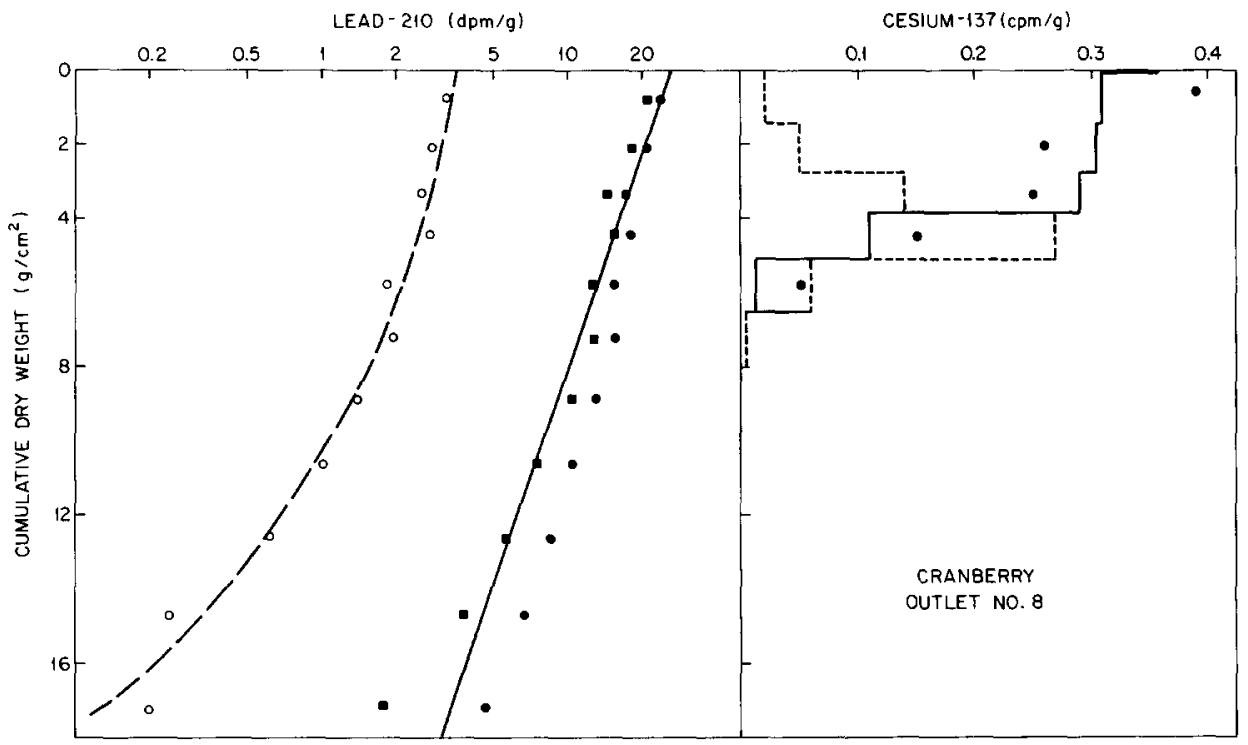

Fig. 16. Distribution of excess $(0)$, total renormalized $(\bullet)$, excess renormalized ${ }^{210} \mathrm{~Pb}(\bullet)$ and ${ }^{137} \mathrm{Cs}$ (right panel) in the Cranberry Outlet Core No. 8 . The curvature in the excess ${ }^{210} \mathrm{~Pb}$ profile is largely removed by re-expressing ${ }^{210} \mathrm{~Pb}$ activities on a weight soluble basis. The dashed-line histogram is the predicted distribution of ${ }^{137} \mathrm{Cs}$ without external system integration. The solid-line histogram is the theoretical contribution with an integration time $\gtrsim 20 \mathrm{yr}$. 
The ${ }^{137} \mathrm{Cs}$ profile (Fig. 16) shows significant activity down to and including the interval from 5.1 to $6.5 \mathrm{~g} \mathrm{~cm}^{-2}$. This result consistent with the accretion rate based on renormalized ${ }^{210} \mathrm{~Pb}$. As the horizon in the ${ }^{137} \mathrm{Cs}$ (onset of introduction) corresponds to $\sim 25 \mathrm{yr}$., the accretion rate (given by the mean cumulative weight in the interval $5.8 \mathrm{~g} \mathrm{~cm}^{-2} / 25 \mathrm{yr}$.) is 0.23 $\mathrm{g} \mathrm{cm}^{-2} \mathrm{yr}^{-1}$ as found from ${ }^{210} \mathrm{~Pb}$. Application of the model to the ${ }^{137} \mathrm{Cs}$ profile gives $0.14 \mathrm{~g} \mathrm{~cm}^{-2} \mathrm{yr}^{-1}$ for $T_{\mathrm{r}}=10 \mathrm{yr}$. and $0.26 \mathrm{~g} \mathrm{~cm}^{-2} \mathrm{yr}^{-1}$ for $T_{\mathrm{r}}$ $\$ 50 \mathrm{yr}$. Thus in this core there is no evidence for migration of ${ }^{137} \mathrm{Cs}$. However, as noted in other cores there is a marked elevation in activity since the

\section{TABLE XII}

Growth rates based on excess ${ }^{210} \mathrm{~Pb}$ profiles uncorrected for variations in the soluble fraction

\begin{tabular}{|c|c|c|c|c|c|}
\hline \multirow{2}{*}{$\begin{array}{l}\text { Core } \\
\text { No. }\end{array}$} & \multirow{2}{*}{$\begin{array}{l}\text { Supported } \\
{ }^{210} \mathrm{~Pb}\left(A_{\mathrm{f}}\right) \\
\left(\text { d.p.m. } \mathrm{g}^{-1}\right)\end{array}$} & \multirow{2}{*}{$\begin{array}{l}\text { Mass accretion rate*1 } \\
\left(\mathrm{g} \mathrm{cm}^{-2} \mathrm{yr}^{-1}\right)\end{array}$} & \multirow{2}{*}{$\begin{array}{l}\text { Mean linear } \\
\text { growth rate } \\
\left(\mathrm{cm} \mathrm{yr} .^{-1}\right)\end{array}$} & \multicolumn{2}{|c|}{ Quality of fit } \\
\hline & & & & $|r|$ & $N$ \\
\hline 1 & $2.0 \pm 2.0$ & \pm 0.04 & 0.32 & 0.97 & 8 \\
\hline 2 & - & $\sim 0$ & $\sim 0$ & $\cdots$ & $\ldots$ \\
\hline 3 & $0.97 \pm 0.5$ & $0.0099 \pm 0.003$ & 0.093 & 0.97 & 4 \\
\hline 4 & $1.8 \pm 1.8$ & $0.10 \pm 0.05$ & 0.29 & 0.99 & 4 \\
\hline 5 & $?$ & $\ldots$ & $\ldots$ & $\ldots$ & $\ldots$ \\
\hline 6 & $1.3 \pm 0.1$ & $0.0053 \pm 0.003$ & 0.044 & 0.93 & 3 \\
\hline 7 & ? & - & - & $\ldots . .$. & -- \\
\hline 8 & $?$ & $\ldots$ & & $\ldots-$ & $-\cdots$ \\
\hline
\end{tabular}

${ }^{*_{1}}$ The indicated error limits include uncertainties in the value of supported ${ }^{210} \mathrm{~Pb}$.

${ }^{*}$ Average over the length of the cove (see text).

\section{TABLE XIII}

Growth rates based on excess ${ }^{210} \mathrm{~Pb}$ profiles corrected for variations in the soluble fraction

\begin{tabular}{|c|c|c|c|c|c|}
\hline \multirow{2}{*}{$\begin{array}{l}\text { Core } \\
\text { No. }\end{array}$} & \multirow{2}{*}{$\begin{array}{l}\text { Supported } \\
{ }^{210} \mathrm{~Pb}\left(A_{\mathrm{f}}\right) \\
\text { (d.p.m. } \mathrm{g}^{-1} \text { sol.) }\end{array}$} & \multirow{2}{*}{$\begin{array}{l}\text { Mass accretion rate } \\
\left(\mathrm{g} \mathrm{cm}^{-2} \mathrm{yr}^{-1}\right)\end{array}$} & \multirow{2}{*}{$\begin{array}{l}\text { Mean linear } \\
\text { growth rate } \\
\left(\mathrm{cm} \mathrm{yr} .^{-1}\right)\end{array}$} & \multicolumn{2}{|c|}{ Quality of fit } \\
\hline & & & & $|r|$ & $N$ \\
\hline 1 & $7.0 \pm 6.0$ & $0.10 \pm 0.02$ & 0.29 & 0.96 & 8 \\
\hline 2 & - & $\sim 0$ & $\sim 0$ & & $\ldots$ \\
\hline 3 & $2.8 \pm 0.5$ & $0.011 \pm 0.003$ & 0.10 & 0.97 & 4 \\
\hline 4 & $5.0 \pm 4.0$ & $0.14 \pm 0.05$ & 0.41 & 0.94 & 7 \\
\hline 5 & $4.0 \pm 4.0$ & $0.47 \pm 0.30$ & $\cdots$ & 0.90 & 7 \\
\hline 6 & $3.8 \pm 0.2$ & $0.005 \pm 0.0029$ & 0.043 & 0.99 & 3 \\
\hline 7 & $8 \pm 6$ & $0.033 \pm 0.007$ & 0.055 & 0.98 & 3 \\
\hline 8 & $3 \pm 1.5$ & $0.23 \pm 0.06$ & 0.23 & 0.98 & 11 \\
\hline
\end{tabular}

${ }^{* 1}$ Value obtained by least-squares fit as the supported ${ }^{210} \mathrm{~Pb}$ (d.p.m. $\mathrm{g}^{-1}$ sol.) could not be determined directly from the total ${ }^{210} \mathrm{~Pb}$ profile.

${ }^{* 2}$ For this core corrections due to systematic variations in the value of the soluble fraction yield significant increases in the estimate of the mass accretion rate. 
period of peak fallout. The effect is particularly noticeable in this core. The dashed line in the figure shows the distribution expected on the basis of the direct transfer model using a value of $0.23 \mathrm{~g} \mathrm{~cm}^{-2} \mathrm{yr}^{-1}$ for the accretion rate. The solid line is the theoretical fit which includes the effects of external integration $\left(T_{\mathrm{r}}=50 \mathrm{yr}\right.$.). While the data favor long-term $(>20-$ $50 \mathrm{yr}$.) integration of inputs, the fit is insensitive to the value of $T_{\mathrm{r}}$ for times exceeding roughly $50 \mathrm{yr}$.

The effect of external integration of inputs on the distribution of radiocesium in this core is further illustrated in Fig. 17. The upper panel shows the calculated distribution for a range of assumed integration time (5-50
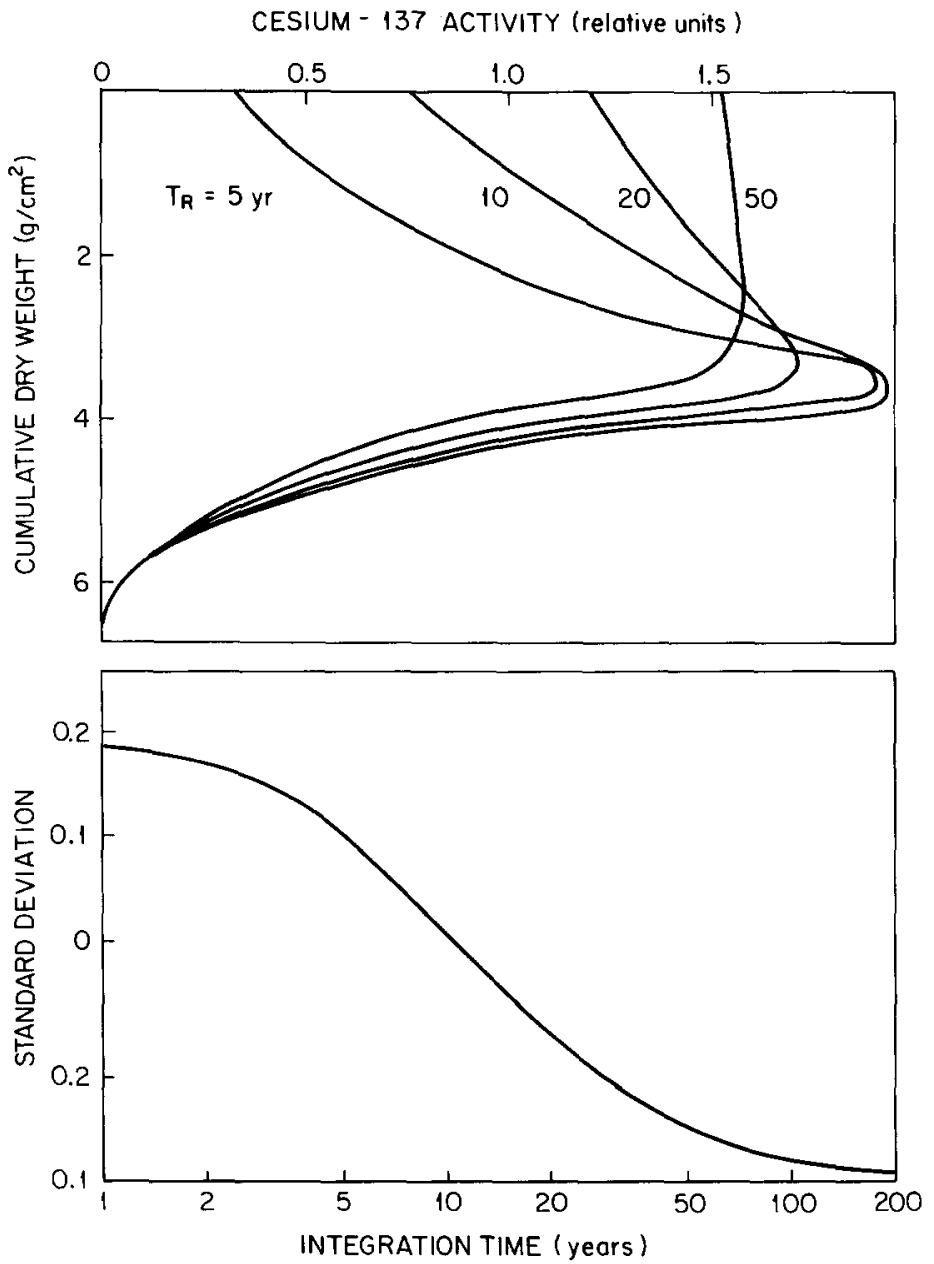

Fig. 17. Upper panel. Theoretical distribution of ${ }^{137} \mathrm{Cs}$ in the Cranberry Outlet Core No. 8 vs, system integration time.

Lower panel. Standard deviation in the fit to actual data vs. the assumed integration time. 
yr.) while the bottom panel provides a measure of the quality of the fit (standard deviation) to the data. Note that a change in integration time in the range of 5-50 yr. has the greatest effect on the quality of the fit. For times greater than $50 \mathrm{yr}$. there is very little additional improvement in the fit. Note also that the external integration process has essentially no effect on the location of the ${ }^{137} \mathrm{Cs}$ horizon. Significant downward diffusion of the isotope would have a direct and appreciable effect on the position of the horizon.

\section{Total activities of radiolead and -cesium}

The total activity of ${ }^{210} \mathrm{~Pb}$ and ${ }^{137} \mathrm{Cs}$ in a core is obtained as the product of the activities (d.p.m. $\mathrm{g}^{-1}$ ) and the mass of material (g dry) summed over all sections. The total activity (d.p.m. $\mathrm{cm}^{-2}$ ) is a measure of the efficiency of transfer of the isotope from the catchment area to the site of the core. For ${ }^{210} \mathrm{~Pb}$ the average rate of deposition in the Great Lakes Region is $\sim 1$ d.p.m. $\mathrm{cm}^{-2} \mathrm{yr}^{-1}$. At a constant rate of deposition, this flux would produce an accumulation of $\sim 32$ d.p.m. $\mathrm{cm}^{-2}$. The data summarized in Table XIV show that in all but one of the cores studied the vertically integrated amount of ${ }^{210} \mathrm{~Pb}$ is less and usually considerably less than 32 d.p.m. $\mathrm{cm}^{-2}$. Thus the overall efficiency of transfer of radiolead from air to this location is generally low. Many factors can contribute to the observed accumulation efficiency: residence time of the isotope in water mass within the wetlands system; efficiency of incorporation of the isotope into the solid matrix; and the residence time of the isotope in the external integration compartment (watershed). ${ }^{137} \mathrm{Cs}$ is transferred to the coring site with about the same

\section{TABLE XIV}

Vertically integrated (total) ${ }^{137} \mathrm{Cs}$ and excess ${ }^{210} \mathrm{~Pb}$ per core

\begin{tabular}{llc}
\hline $\begin{array}{l}\text { Core } \\
\text { No. }\end{array}$ & $\begin{array}{l}\text { Total }{ }^{137} \mathrm{Cs} \\
\left(\text { d.p.m. } \mathbf{c m}^{-2}\right)\end{array}$ & $\begin{array}{l}\text { Total excess }{ }^{210} \mathrm{~Pb} \\
\left(\text { d.p.m. } \mathbf{c m}^{-2}\right)\end{array}$ \\
\hline 1 & 2.48 & 42.7 \\
2 & 0 & $\sim 0$ \\
3 & 0.46 & 6.22 \\
4 & 0.44 & 8.86 \\
5 & 0.30 & 13.8 \\
6 & 0.25 & 3.1 \\
7 & 0.72 & 12.9 \\
8 & 1.4 & 22.5 \\
Approximate value from atmospheric deposition & $2.3^{* 1}$ & $32^{* 2}$ \\
\hline
\end{tabular}

*1 Integrated atmospheric deposition corrected for decay to 1980 is 15.6 d.p.m. cm ${ }^{2}$ (Edgington and Kartunnen, 1977). As the detector efficiency is $\sim 7$ d.p.m./c.p.m. the expected total counts per minute $/ \mathrm{cm}^{2}$ is $15.6 / 7=2.3$.

${ }^{* 2}$ Based on an annual flux of 1 d.p.m. $\mathrm{cm}^{-2} \mathrm{yr}^{-1}$ (Robbins, 1978). 
efficiency. The relation between total ${ }^{210} \mathrm{~Pb}$ (excess) and total ${ }^{137} \mathrm{Cs}$ in each core is shown in Fig. 18. With the exception of core No. 5 (Pentwater North Branch), total activities are very well correlated $(r=0.996 ; n=7)$. The dashed lines in the figure indicate total activities based on direct deposition. The integrated atmospheric deposition of ${ }^{137} \mathrm{Cs}\left(15.6 \mathrm{~d} . \mathrm{p} . \mathrm{m} . \mathrm{cm}^{-2}\right)$ is decay corrected to 1980. As the isotopes have very different deposition time dependences $\left({ }^{210} \mathrm{~Pb}\right.$, steady state; ${ }^{137} \mathrm{Cs}$, strongly non-steady state) but a similar affinity for fine-grained particles in aquatic environments, the good correlation argues in favor of particle trapping efficiency as the primary factor affecting the accumulation of both isotopes at the coring sites.

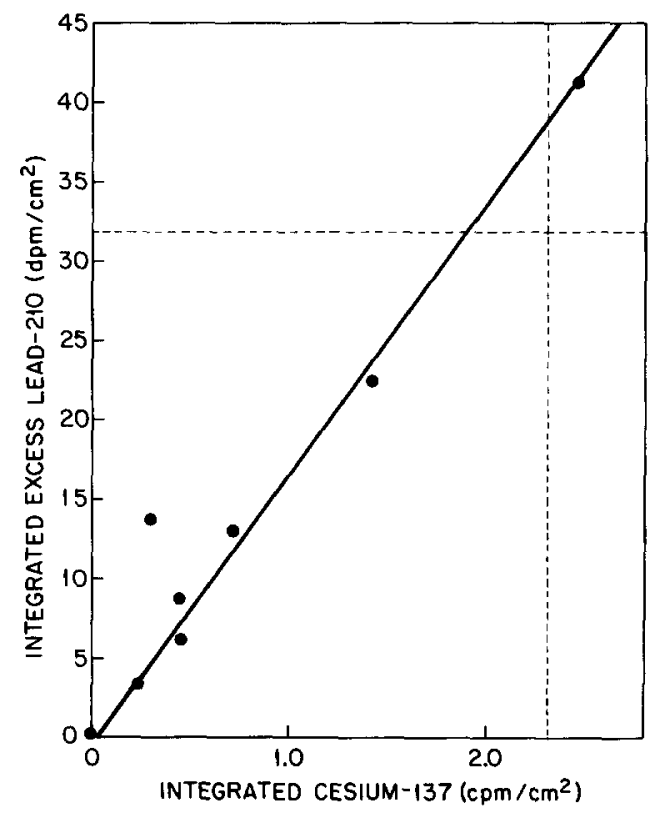

Fig. 18. Relation between total ${ }^{137} \mathrm{Cs}$ and total ${ }^{210} \mathrm{~Pb}$ in the cores. Most cores contain far less than expected from direct atmospheric transfer. The good correlation between the two nuclides, having very different input time dependences, reflects common processes resulting in their accumulation in the wetlands system.

\section{CONCLUSIONS}

The net effect of the two wetland systems investigated on the sediment load to the Great Lakes appeared to be negligible. Although Cranberry Bog No. 1, the forested bottomland ecosystem, tends to export a good fraction of its organic detritus, the receiving filling-lake-bog system of Cranberry Bog No. 2 appears to retain much of this material. The Cranberry Bog system appears to receive a significant amount of groundwater as a contribu- 
tion to the net pool. This is not unexpected in the highly porous sand dune watershed in which they are located.

Similar soils and topography surround the Pentwater Marsh, and may contribute a like amount of discharge water, but the flow of the Pentwater River is much higher than the flows to the Cranberry Bogs. Consequently there is a large amount of suspended material that enters this wetland system via the river. To a first approximation, this same amount of suspended material leaves the Pentwater Marsh. There are undoubtedly differences in the mineral character of these sediments on seasonal and geographical bases, but there is no great sediment trapping action in this river-delta wetland.

The ${ }^{210} \mathrm{~Pb}$ method is of value in determining the rates of accretion of wetlands but future studies should include determination of supported ${ }^{210} \mathrm{~Pb}$ activities and provide better documentation of gross stratigraphic changes in cores. ${ }^{137} \mathrm{Cs}$ appears to be largely immobile in the materials studied but the depth of occurrence is generally so limited as to make it a dubious geochronological tool. In cores where accretion rates are high enough to resolve details in $\mathrm{Cs}$ profiles, activities are generally higher in near-surface sections than expected from the fallout record. Elevated levels are tentatively ascribed to a process of integration external to the coring site. This would be the case if the main source of the isotope were a catchment area storing fallout for residence times the order of $20 \mathrm{yr}$. or more. In most cores (6 out of 8 ) integrated activities of both isotopes are much less than expected for direct atmospheric transfer. Reduced transfer efficiencies result from scavenging and residence time effects within the catchment area.

The accretion rates as inferred from these measurements are shown in Figs. 8 and 11 for the three wetland systems. It can be seen in Fig. 8 that accretion rates are very much higher in Cranberry Bog No. 2 than in Cranberry Bog No. 1. Further, the amount of soluble material depositing in Cranberry Bog No. 1 is larger in percentage than it is in Cranberry Bog No. 2 . This is consistent with the deposition of organic material within Cranberry Bog No. 2. Accretion rates in the Pentwater system are extremely variable as shown in Fig. 11. Areas that are subjected to flushing by either streamflow or by action of wind and waves show small accretion rates compared to those areas which receive a higher organic loading due to internal cycling and water-borne sediments. Stream channels are scoured according to the radiometric analyses.

The sediment accretion rates observed are in agreement with the observed amounts of sediments entering and leaving all three wetland ecosystems. Small sediment retention resulted in small accretion measured in the core studies. Soil accretion rates are low compared to other reported literature values. Cranberry Bog No. 2 clearly shown a greater accretion rate than Cranberry Bog No. 1, which is again the agreement with the observed import and export character of the wetlands.

Rainfall events in these wetlands did not have a large effect on the import 
or export of sediments. This is believed to be due to the nature of the watershed, in which sandy soils mediate the runoff of rain waters. Since rain events do not stimulate large or sudden increased in streamflow, they do not resuspend and export large amounts of sediments.

It is noteworthy that both the Cranberry Bogs system and the Pentwater system export relatively large concentrations of suspended material during the winter months. Spring runoff carries significant amounts of the total annual sediment loads from these sites.

In summary, it appears as though the bottomland, forested intradunal wetland exports solids. The open-water filling-bog system acts as a sedimentation basin and collects sediments. The periodically inundated river-delta wetland has no significant effect on the suspended-solids load of the river entering the lake. Rainfall events do not cause sudden flushes at any of the three sites studied, but seasonal effects were large.

\section{ACKNOWLEDGEMENT}

This publication is a result of work sponsored by the Michigan Sea Grant Program, project No. R/C W-8, with a grant, NA-80-AA-D-00072, from the Office of Sea Grant, National Oceanic and Atmospheric Administration (N.O.A.A.), U.S. Department of Commerce, and funds from the State of Michigan. The U.S. Government is authorized to produce and distribute reprints for governmental purposes notwithstanding any copyright notification appearing hereon.

\section{REFERENCES}

A.P.H.A. (American Public Health Association), 1976. Standard Methods for the Examination of Water and Wastewater. Am. Publ. Health Assoc. (A.P.H.A.)-Am. Water Works Assoc. (A.W.W.A.)-Water Pollut. Control. Fed. (W.P.C.F.), Washington, D.C., 14 th ed., 1193 pp.

Appleby, P.G. and Oldfield, F., 1978. The calculation of lead-210 dates assuming a constant rate of supply of unsupported ${ }^{210} \mathrm{~Pb}$ to the sediment. Catena, 5: 1--8.

Armentano, T. and Woodwell, G., 1975. Sedimentation rates in a Long Island marsh determined by lead-210 dating. Limnol. Oceanogr., 20: 452-456.

Boto, K.G. and Patrick, Jr., W.H., 1979. Role of wetlands in the removal of suspended sediments. In: P.E. Greeson, J.R. Clark and J.E. Clark (Editors), Wetland Functions and Values; The State of Our Understanding. American Water Resources Association, Minneapolis, Minn., pp. 479-489.

DeLaune, R.D., Patrick, Jr., W.H. and Buresh, R.J., 1978. Sedimentation rates determined by 137-Cs dating in a rapidly accreting salt marsh. Nature (London), 275: $532-533$.

Edgington, D.N. and Kartunnen, J., 1977. Distribution of cesium-137 in Lake Erie. Radiol. Environ. Res. Div., Annu. Rep., Ecol. Jan.--Dec. 1977. ANL-77-65, Part III. Argonne Natl. Lab., Argonne, Ill., pp. 105-110.

El-Daoushy, F., Tolonen, K. and Rosenberg, R., 1982. Lead-210 and moss-increment dating of two Finnish Sphagnum hummocks. Nature (London), 296 (5856): 429-431. 
Gustafson, P.F., Nelson, D.M., Brar, S.S. and Muniak, S.E., 1970. Recent trends in radioactive fallout. Radiol. Phys. Div., Annu. Rep., Environ. Stud., July 1969-Dec. 1970, ANL-7760, Part III, Argonne Natl. Lab., Argonne, Ill., pp. 245-248.

H.A.S.L. (Health and Safety Laboratory), 1977. Final tabulation of monthly ${ }^{90} \mathrm{Sr}$ fallout data: 1954- 1976. Health Safety Lab., Energy Res. Dev. Adm., New York, N.Y., HASL-329, p. 401.

Kadlec, R.H. and Kadlec, J.A., 1979. Wetlands and water quality. In: P.E. Greeson, J.R. Clark and J.E. Clark (Editors), Wetland Functions and Values: The State of Our Understanding. American Water Resources Association, Minneapolis, Minn., pp. 436456 .

Oldfield, F., Appleby, P.G., Cambray, R.S., Eakins, J.D., Barber, K.E., Battarbe, R.W., Pearson, G.R. and Williams, J.M., $1979 .{ }^{210} \mathrm{~Pb},{ }^{137} \mathrm{Cs}$ and ${ }^{239} \mathrm{Pu}$ profiles in ombrotrophic peat. Oikos, 33: 40-45.

Pakarinen, P. and Tolonen, K., 1977. Pintaturpeen kasvunopeudesta - Kasvunopeudesta ja ajoittamisesta. Suo, 28(1): 19-24.

Ranwell, D.S., 1964. Spartina salt marshes in southern England, II. Rate and seasonal pattern of sediment accretion. J. Ecol., 52: 79-94.

Richard, G.A., 1978. Seasonal and environmental variations in sediment accretion in a Long Island salt marsh. Estuaries, 1(1): 29--35.

Robbins, J.A., 1978. Geochemical and geophysical applications of radioactive lead isotopes. In: J.O. Nriagu (Editor), Biogeochemistry of Lead in the Environment. Elsevier, Amsterdam, pp. 285-393.

Robbins, J.A., 1980. Sediments of southern Lake Huron: Elemental composition and accumulation rates. U.S. Environ. Prot. Agency, Ecol. Res. Ser., Aug. 1980, EPA600/3-80-080, p. 309 (plus appendix, p. 198).

Robbins, J.A. and Edgington, D.N., 1975. Determination of recent sedimentation rates in Lake Michigan using Pb-210 and Cs-137. Geochim. Cosmochim. Acta, 39: 285304.

Thornthwaite, C.W. and Mather, J.R., 1957. Instructions and tables for computing potential evapotranspiration and the water balance. Publ. Climatol., 10: 3 .

Tilton, D.L., Kadlec, R.H. and Schwegler, B.R., 1978. The ecology and values of Michigan's Coastal Wetlands. In: Coastal Wetlands Value Study in Michigan. Mich. Coastal Manage. Prog., Lansing, Mich., Phase II. 